\title{
Soil greenhouse gas fluxes from different tree species on Taihang Mountain, North China
}

\author{
X. P. Liu ${ }^{1}$, W. J. Zhang ${ }^{1}$, C. S. Hu ${ }^{1}$, and X. G. Tang ${ }^{2}$ \\ ${ }^{1}$ Key Laboratory of Agricultural Water Resources, Hebei Key Laboratory of Agricultural Water-Saving, Center for \\ Agricultural Resources Research, Institute of Genetics and Developmental Biology, Chinese Academy of Sciences, \\ Shijiazhuang 050021, China \\ ${ }^{2}$ Key Laboratory of Wetland Ecology and Environment, Northeast Institute of Geography and Agroecology, Chinese \\ Academy of Sciences, 3195 Weishan Road, Changchun 130012, China
}

Correspondence to: W. J. Zhang (zhangwj@sjziam.ac.cn)

Received: 9 June 2013 - Published in Biogeosciences Discuss.: 4 July 2013

Revised: 6 December 2013 - Accepted: 6 December 2013 - Published: 27 March 2014

\begin{abstract}
The objectives of this study were to investigate seasonal variation of greenhouse gas fluxes from soils on sites dominated by plantation (Robinia pseudoacacia, Punica granatum, and Ziziphus jujube) and natural regenerated forests (Vitex negundo var. heterophylla, Leptodermis oblonga, and Bothriochloa ischcemum), and to identify how tree species, litter exclusion, and soil properties (soil temperature, soil moisture, soil organic carbon, total $\mathrm{N}$, soil bulk density, and soil $\mathrm{pH}$ ) explained the temporal and spatial variation in soil greenhouse gas fluxes. Fluxes of greenhouse gases were measured using static chamber and gas chromatography techniques. Six static chambers were randomly installed in each tree species. Three chambers were randomly designated to measure the impacts of surface litter exclusion, and the remaining three were used as a control. Field measurements were conducted biweekly from May 2010 to April 2012. Soil $\mathrm{CO}_{2}$ emissions from all tree species were significantly affected by soil temperature, soil moisture, and their interaction. Driven by the seasonality of temperature and precipitation, soil $\mathrm{CO}_{2}$ emissions demonstrated a clear seasonal pattern, with fluxes significantly higher during the rainy season than during the dry season. Soil $\mathrm{CH}_{4}$ and $\mathrm{N}_{2} \mathrm{O}$ fluxes were not significantly correlated with soil temperature, soil moisture, or their interaction, and no significant seasonal differences were detected. Soil organic carbon and total $\mathrm{N}$ were significantly positively correlated with $\mathrm{CO}_{2}$ and $\mathrm{N}_{2} \mathrm{O}$ fluxes. Soil bulk density was significantly negatively correlated with $\mathrm{CO}_{2}$ and $\mathrm{N}_{2} \mathrm{O}$ fluxes. Soil $\mathrm{pH}$ was not correlated with $\mathrm{CO}_{2}$ and $\mathrm{N}_{2} \mathrm{O}$ emissions. Soil $\mathrm{CH}_{4}$ fluxes did not dis-
\end{abstract}

play pronounced dependency on soil organic carbon, total $\mathrm{N}$, soil bulk density, and soil $\mathrm{pH}$. Removal of surface litter significantly decreased in $\mathrm{CO}_{2}$ emissions and $\mathrm{CH}_{4}$ uptakes. Soils in six tree species acted as sinks for atmospheric $\mathrm{CH}_{4}$. With the exception of Ziziphus jujube, soils in all tree species acted as sinks for atmospheric $\mathrm{N}_{2} \mathrm{O}$. Tree species had a significant effect on $\mathrm{CO}_{2}$ and $\mathrm{N}_{2} \mathrm{O}$ releases but not on $\mathrm{CH}_{4}$ uptake. The lower net global warming potential in natural regenerated vegetation suggested that natural regenerated vegetation were more desirable plant species in reducing global warming.

\section{Introduction}

Carbon dioxide $\left(\mathrm{CO}_{2}\right)$, methane $\left(\mathrm{CH}_{4}\right)$, and nitrous oxide $\left(\mathrm{N}_{2} \mathrm{O}\right)$ are three major greenhouse gases $(\mathrm{GHG})$ that contribute to global warming (Lang et al., 2010). Forest soils have been identified as sinks for $\mathrm{CH}_{4}$ (Tang et al., 2006; Liu et al., 2008; Luo et al., 2012), and sources of $\mathrm{CO}_{2}$ and $\mathrm{N}_{2} \mathrm{O}$ (Tang et al., 2006; Liu et al., 2008; Peichl et al., 2010; Christiansen et al., 2012). Differences in forest types (Tang et al., 2006; Zheng et al., 2008), successional stages (Law et al., 2001; Peichl et al., 2010), and human activities (Yang et al., 2005; Sharma et al., 2011), such as deforestation and reforestation, have been shown to affect GHG fluxes. Many studies have indicated that tree species are an important determinant of GHG fluxes (Dewar and Cannell, 1992; Grigal and Ohmann, 1992; Borken et al., 2003; Borken and Beese, 2005; 
Vesterdal et al., 2008, 2012; Zheng et al., 2008). Vesterdal et al. (2008) found that different tree species planted on the same site were linked with different amounts of soil organic carbon (SOC), especially in forest floor carbon pools. Vesterdal et al. (2012) later pointed out that soil $\mathrm{CO}_{2}$ effluxes differed significantly among tree species and sites over the year in Denmark. Borken et al. (2003) reported a strong influence of forest type on the soil $\mathrm{CH}_{4}$ sink, based on an investigation of natural mature beech forests and mature pine and spruce plantations in two study areas in Germany. On the contrary, Borken and Beese (2005) observed no differences in soil $\mathrm{N}_{2} \mathrm{O}$ emissions between European beech, Scots pine and Norway spruce forests in two study areas in Germany with distinct climate, $\mathrm{N}$ deposition and soils. However, few studies have reported GHG fluxes from different tree species within similar climates and soils (Post and Kwon, 2000; Ladegaard-Pedersen et al., 2005; Berger et al., 2010). Therefore, determining how tree species influence soil $\mathrm{CO}_{2}$, $\mathrm{CH}_{4}$, and $\mathrm{N}_{2} \mathrm{O}$ emissions are necessary steps in assessing potential impacts of environmental change (Raich and Tufekcioglu, 2000).

The wide range of magnitude and uncertainty in GHG exchanges from soils arises from soil-plant system heterogeneity and from the complex interactions among the physical, chemical, and biological variables controlling their respective production and consumption (Liu et al., 2006; Peichl et al., 2010). $\mathrm{CO}_{2}, \mathrm{CH}_{4}$, and $\mathrm{N}_{2} \mathrm{O}$ exchanges are dependent on a number of parameters that may affect gas diffusivity, soil aeration, and soil microorganisms, such as soil temperature (ST), soil moisture (SM), bulk density (BD), litter layer characteristics, and substrate supply and quality (Campbell and Law, 2005; Davidson et al., 2006; Vose and Bolstad, 2006; Peichl et al., 2010).

Taihang Mountain in northern China has been overexploited for farming, grazing, and timber production. Therefore, most plant communities in the area are in a secondary stage of disturbance following the near complete eradication of primary, broad-leaved deciduous forests (Zhang et al., 2006). Most forests have been converted to shrubs or herbaceous vegetation resulting in a deterioration of their ecological environment, with some areas experiencing desertification and a near complete lack of vegetation (Liu et al., 2010, 2011). In 1999, the Chinese government initiated the Grainfor-Green (GfG) program designed to reduce the deterioration of natural forests and grasslands, increase vegetation coverage on steep slopes, protect water resources, and promote sustainable development in mountainous areas (Zhang et al., 2000). The large scale of afforestation, along with the restoration of natural forests under the GfG program on Taihang Mountain, both substantially affect SOC dynamics ( $\mathrm{Li}$ et al., 2002; Zhang et al., 2010) and hence the exchange of GHGs between the soil and atmosphere (Zhou et al., 2004).

Understanding the effects of tree species from new plantations and naturally regenerated forests on GHG emissions can provide important information for ecosystem manage- ment practices and international policies to mitigate greenhouse gas emissions (Canadell and Raupach, 2008; Zhang et al., 2010). However, a comprehensive assessment of GHG fluxes from different types of trees on new plantations and naturally regenerated forests has not been reported in China to date. The objectives of this study were to: (1) investigate the seasonal variation of GHG fluxes from soils planted with different tree species on new plantations and naturally regenerated forests; and (2) identify how tree species, litter exclusion and soil properties (ST, SM, SOC, total N (TN), BD and $\mathrm{pH}$ ) can help explain the temporal and spatial variation in greenhouse gas fluxes from soils on Taihang Mountain.

\section{Materials and methods}

\subsection{Site description}

The study site is located in Niujiazhuang Catchment (area: $\left.9.3 \mathrm{~km}^{2}\right)$ in the middle of Taihang Mountain $\left(114^{\circ} 15^{\prime} 50^{\prime \prime} \mathrm{E}\right.$, $37^{\circ} 52^{\prime} 44^{\prime \prime} \mathrm{N}$ ), which is situated approximately $50 \mathrm{~km}$ southwest of the city of Shijiazhuang, the capital city of Hebei Province in northern China (Fig. 1). The catchment is the site of the Hilly Ecosystem Experimental Station in Taihang Mountain which is run by the Chinese Academy of Sciences. Elevation ranges from 247 to $1040 \mathrm{~m}$ a.s.l., with slopes in the catchment ranging from 20 to $45^{\circ}$. The climate is generally dry from October to May and rainy from June to September. Annual precipitation averages $560 \mathrm{~mm}$, ranging from 390 to $750 \mathrm{~mm}$, with nearly $68 \%$ occurring between June and September. Annual evaporation averages $1934 \mathrm{~mm}$. The long-term average annual temperature is $13^{\circ} \mathrm{C}$ (ranging from $-1.6^{\circ} \mathrm{C}$ in January to $26.3^{\circ} \mathrm{C}$ in July).

Parent materials in the study area are composed primarily of granite, granite porphyry, limestone, sandstone, and shale. Soils in the area are generally classified as mountainous cinnamon soils (Ustalf), which are calcareous soils formed mainly from the weathering of gneissic granitoids, partly by limestone and shale. Soil depth in the study area varies from approximately $20 \mathrm{~cm}$ on south-facing slopes to $120 \mathrm{~cm}$ on north-facing slopes. Soils are generally poorly stratified with a thin $\mathrm{O}$ horizon ( 0 to $2 \mathrm{~cm}$ in thickness) and poorly developed A ( 3 to $10 \mathrm{~cm})$ and B horizons $(20$ to $70 \mathrm{~cm})$, and contain abundant gravel. The soils are well-drained and generally nutrient-poor, with a weak capacity to retain fertilizer and water.

Vegetation in the catchment is a mosaic of shrubs, herbs, plantation, deciduous and coniferous forests, and agricultural crops. The naturally regenerated shrub-herb community is dominated by $V$. negundo var. heterophylla, L. oblonga, Z. jujuba var. spinosa, B. ischcemum, A. sacrorum, and $T$. japonica. The planted species are $R$. pseudoacacia, P. granatum, and Z. jujube, Diospyros kaki, J. regia, and Armeniaca sibirica. $R$. pseudoacacia is widely used in reforestation, forest shelter construction, and various ecological 


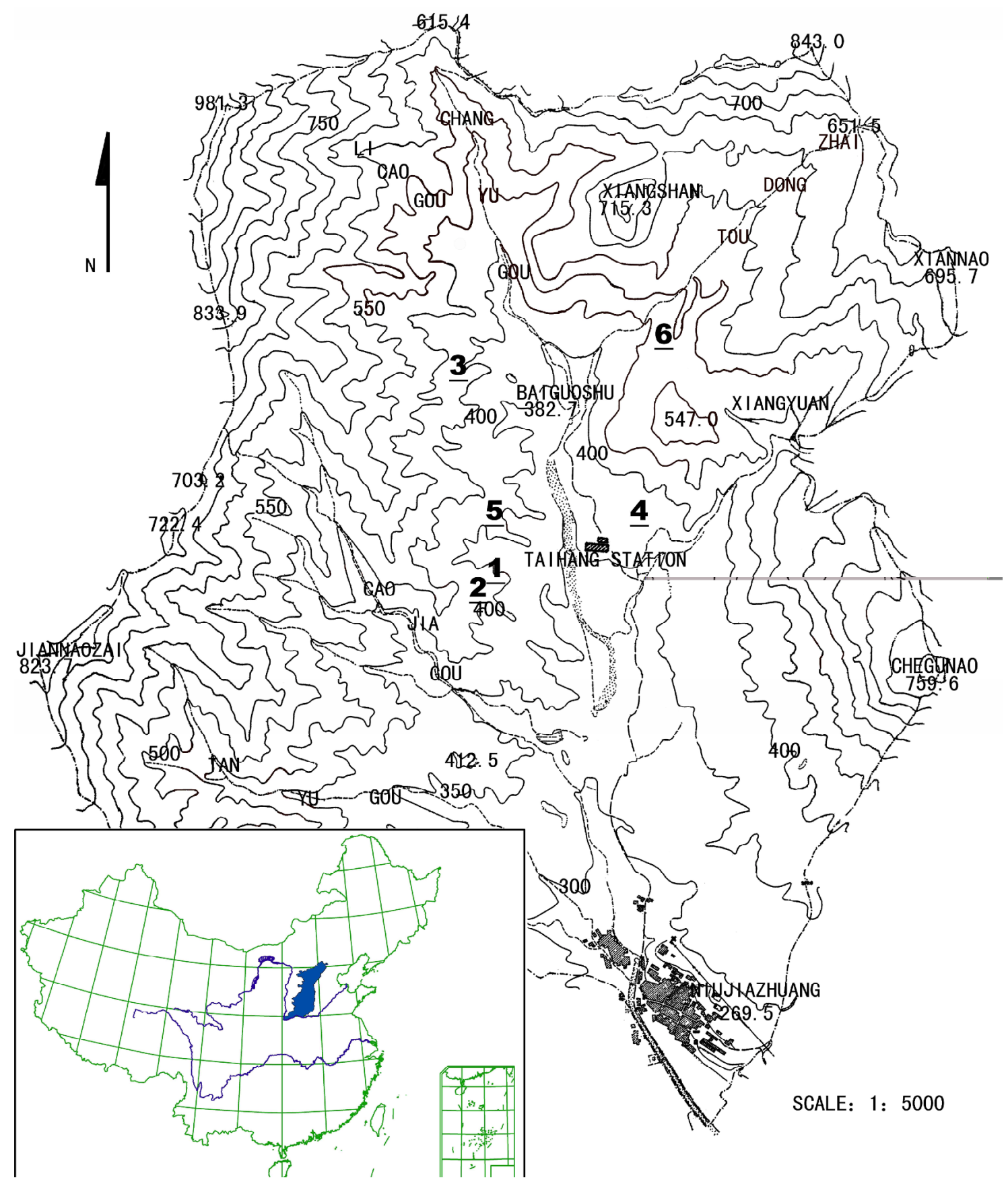

Fig. 1. Locations of six sampling plots in six tree species in Niujiazhuang Catchment on Taihang Mountain in Northern China. 1 is Robinia pseudoacacia; 2 is Vitex negundo var. heterophylla; 3 is Leptodermis oblonga; 4 is Punica granatum; 5 is Ziziphus jujube; and 6 is Bothriochloa ischcemum.

projects in China. P. granatum and Z. jujube are typical tree species planted on Taihang Mountain. V. negundo var. heterophylla, L. oblonga, and $B$. ischcemum are representative of the naturally regenerated vegetation on Taihang Mountain. Therefore, as representative tree species, $R$. pseudoacacia, P. granatum, Z. jujube, V. negundo var. heterophylla, L. oblonga, and B. ischcemum were selected to represent both naturally regenerated and managed vegetation in the region. One sampling plot $(20 \mathrm{~m} \times 20 \mathrm{~m})$ was randomly chosen for each tree species to be the representative of that vegetation. The dominant species and the main characteristics of each of the plots are listed in Table 1 .

R. pseudoacacia forests are the most common forest in middle Taihang Mountain. They were developed from a 
Table 1. General characteristics for six tree species located on Taihang Mountain in Northern China*.

\begin{tabular}{|c|c|c|c|c|c|c|c|c|c|c|}
\hline Site & $\begin{array}{l}\text { Elevation } \\
(\mathrm{m})\end{array}$ & $\begin{array}{l}\text { Slope } \\
\left(^{\circ}\right)\end{array}$ & $\begin{array}{l}\text { Slope } \\
\text { aspect }\end{array}$ & $\begin{array}{l}\text { Forest } \\
\text { type }\end{array}$ & $\begin{array}{l}\text { Age } \\
\text { (year) }\end{array}$ & $\begin{array}{l}\text { Height } \\
\text { (m) }\end{array}$ & Understory & $\begin{array}{r}\text { Forest } \\
\text { coverage } \\
(\%)\end{array}$ & $\begin{array}{r}\text { Root } \\
\text { biomass } \\
\left(\mathrm{g} \mathrm{m}^{-2}\right)\end{array}$ & $\begin{array}{c}\text { Litter } \\
\text { biomass } \\
\left(\mathrm{g} \mathrm{m}^{-2}\right)\end{array}$ \\
\hline $\begin{array}{l}\text { Robinia } \\
\text { pseudoacacia }\end{array}$ & 469 & 30 & East & $\begin{array}{l}\text { Deciduous } \\
\text { arbor }\end{array}$ & 20 & 5.8 & $\begin{array}{l}1,2,3,4,6,8 \\
11,13,14\end{array}$ & 91.9 & 3845 & 569 \\
\hline $\begin{array}{l}\text { Vitex negundo var. } \\
\text { heterophylla }\end{array}$ & 531 & 31 & South & $\begin{array}{l}\text { Deciduous } \\
\text { shrub }\end{array}$ & - & 1.6 & $\begin{array}{l}2,3,4,5,6,7 \\
8,9,10\end{array}$ & 95.2 & 1266 & 677 \\
\hline $\begin{array}{l}\text { Leptodermis } \\
\text { oblonga }\end{array}$ & 493 & 36 & North & $\begin{array}{l}\text { Deciduous } \\
\text { shrub }\end{array}$ & - & 0.6 & $\begin{array}{l}2,3,4,7,10 \\
11,12\end{array}$ & 93.7 & 1200 & 650 \\
\hline Punica granatum & 489 & 32 & South & $\begin{array}{l}\text { Deciduous } \\
\text { small arbor }\end{array}$ & 20 & 3.3 & $\begin{array}{l}2,3,4,5,6,7 \\
10,13\end{array}$ & 77.0 & 2420 & 488 \\
\hline Ziziphus jujube & 464 & 30 & South & $\begin{array}{l}\text { Deciduous } \\
\text { small arbor }\end{array}$ & 20 & 4.6 & $\begin{array}{l}2,3,5,6,8,13, \\
14,15,16\end{array}$ & 78.3 & 2000 & 466 \\
\hline $\begin{array}{l}\text { Bothriochloa } \\
\text { ischcemum }\end{array}$ & 635 & 34 & North & $\begin{array}{l}\text { Perennial } \\
\text { herb }\end{array}$ & - & 0.4 & $\begin{array}{l}2,3,4,5,6,7 \\
8,9,10,11,12\end{array}$ & 100.0 & 922 & 520 \\
\hline
\end{tabular}

Note: *: Data are cited from Liu et al. (2010, 2011). Soil properties were measured at 0 to $10 \mathrm{~cm}$ depth.

1, Vitex negundo var. heterophylla; 2, Artemisia sacrorum; 3, Bothriochloa ischcemum; 4, Themeda japonica; 5, Cleistogenes chinensis; 6, Setaria viridis; 7, Festuca ovina; 8, Rubia cordifolia; 9, Dianthus chinensis; 10, Dendranthema indicum; 11, Bupleurum chinense; 12, Euphorbia pekinensis; 13, Ziziphus jujuba var. spinosa; 14, Bidens pilosa; 15, Salsola collina; 16, Rehmannia glutinosa

sparsely planted secondary forest and experienced a gradual invasion of V. negundo var. heterophylla through natural succession. The overstory trees have an average diameter of $4.5 \mathrm{~cm}$ at breast height and an average height of $5.8 \mathrm{~m}$.

The $P$. granatum and $Z$. jujube forests were established by local residents in the 1990s, and are distributed primarily in the lands near villages at lower elevation and with gentle slopes. These sites have a long history of human disturbance. Prior to planting, these sites were primarily scrublands, containing species such as $V$. negundo var. heterophylla or L. oblonga. Since planting, these forests have been generally managed using mineral fertilization (nitrogen $(\mathrm{N})$, phosphorus (P), and potassium (K)), as well as herbicide and pesticide applications. Annual rates of inorganic N, phosphorus pentoxide $\left(\mathrm{P}_{2} \mathrm{O}_{5}\right)$, and potassium oxide $\left(\mathrm{K}_{2} \mathrm{O}\right)$ supplied to $P$. granatum and $Z$. jujube forests have typically averaged approximately 200,150 , and $150 \mathrm{~kg} \mathrm{ha}^{-1}$, respectively, applied in the fall and 150,100, and $100 \mathrm{~kg} \mathrm{ha}^{-1}$ applied in the spring (Table 2). Neither fertilizer nor manure was applied during the experiment outlined in this paper. The P. granatum trees had an average basal diameter of $6.0 \mathrm{~cm}$, and an average height of $3.25 \mathrm{~m}$. The $Z$. jujube trees had an average diameter at breast height (dbh) of $2.8 \mathrm{~cm}$ and an average height of $4.63 \mathrm{~m}$.

The V. negundo var. heterophylla, L. oblonga, and B. ischcemum forests have been protected from human disturbance for more than 20 years. L. oblonga is accustomed to growing in the shade, whereas $V$. negundo var. heterophylla prefers dryness. B. ischcemum, a kind of perennial herbage, is found on shaded sites. The mean heights of $V$. negundo var. heterophylla, L. oblonga, and B. ischcemum were 1.60, 0.59 , and $0.44 \mathrm{~m}$, respectively. Forest coverage on the sam- pling plots was generally over $90 \%$, and on some sites the coverage of L. oblonga and B. ischcemum reached $100 \%$.

\subsection{Measurement of fluxes}

Six static chambers were randomly installed on each plot. Three of the chambers were randomly designated to measure the effect of surface litter exclusion (i.e. bare soil or BS treatment), and the remaining three were used as the control (i.e. soil with surface litter or SL treatment). For the BS treatment, litter was removed carefully at least $1 \mathrm{~h}$ before each sampling (Liu et al., 2008). Field measurements were conducted biweekly (total of 6 tree species $\times 2$ treatments $\times 3$ replicates $\times 48$ times $=1728$ ) from May 2010 to April 2012 .

The static chamber consisted of a permanently installed polyvinyl chloride base (without top and bottom, $30 \mathrm{~cm}$ in length, $20 \mathrm{~cm}$ in width, and 5 and $15 \mathrm{~cm}$ in height on the upper and the lower slopes with slopes in the catchment ranging from 20 to $45^{\circ}$, respectively) with a $\mathrm{U}$-shaped groove at the top edge to hold a mobile polymethyl methacrylate cover box (without bottom, $30 \mathrm{~cm} \times 20 \mathrm{~cm} \times 30 \mathrm{~cm}$ ). With the lid placed on the base, the groove was filled with water to a depth of $5 \mathrm{~cm}$, which acted as an air seal. A battery-operated fan inside the polymethyl methacrylate box homogenized the air in the chamber. The cover was fitted with a temperature sensor and a three-way sampling stopcock (Liu et al., 2008). Sampling was conducted between 9.00 and 11.00 in the morning. Gas samples $(50 \mathrm{~mL}$ each) were collected with a $60 \mathrm{~mL}$ gas-tight syringe $10,20,30$ and $40 \mathrm{~min}$ after closure through a tube inserted into the chamber headspace. Air samples were transferred from the syringe into a preevacuated $150 \mathrm{~mL}$ aluminum foil gas-collecting bag (Dalian Delin Gas Packing Co., Ltd, China) in the field. $\mathrm{CO}_{2}, \mathrm{CH}_{4}$, and $\mathrm{N}_{2} \mathrm{O}$ concentrations in the samples were analyzed in 
Table 2. The main management measures of plantations.

\begin{tabular}{llll}
\hline & Fertilizing & Watering & Weeding \\
\hline Robinia pseudoacacia & No & $\begin{array}{l}\text { Watering in the first year } \\
\text { of planting to ensure survival }\end{array}$ & No \\
Punica granatum & $\begin{array}{l}\text { Twice a year } \\
\text { (autumn and spring) }\end{array}$ & $\begin{array}{l}\text { Three times a year (flowering, } \\
\text { fruiting, and harvesting periods) }\end{array}$ & $\begin{array}{l}\text { Twice a year } \\
\text { (summer) }\end{array}$ \\
Ziziphus jujube & $\begin{array}{l}\text { Twice a year } \\
\text { (autumn and spring) }\end{array}$ & No & $\begin{array}{l}\text { Twice a year } \\
\text { (summer) }\end{array}$ \\
\hline
\end{tabular}

the laboratory within 1 week of collection. An HP 4890 gas chromatograph (Agilent Technologies, Palo Alto, California, USA) equipped with an electron capture detector (ECD) was used for $\mathrm{N}_{2} \mathrm{O}$ detection at $330^{\circ} \mathrm{C}$. A methanizer and a flame ionization detector (FID) were used for $\mathrm{CH}_{4}$ and $\mathrm{CO}_{2}$ detection at $200^{\circ} \mathrm{C}$. The gas chromatography configurations and calculation of the fluxes of each gas followed procedures described by Wang and Wang (2003) and Yao et al. (2010). Data from individual collars occasionally had to be discarded if changes in gas concentrations did not follow a constant linear increase or decrease. GHG flux was calculated based on the rate of change in GHG concentration within the chamber, which was estimated as the slope of the linear regression between concentration and time (Liu et al., 2008). All coefficients of determination ( $r^{2}$ values) for the linear regressions in the study were greater than 0.80 (the success rate of flux measurements was more than $98 \%$ for $\mathrm{CO}_{2}$ and $85 \%$ for $\mathrm{CH}_{4}$ and $\mathrm{N}_{2} \mathrm{O}$ ).

\subsection{Calculation of fluxes}

Gas flux was estimated using the following equation:

$J=\rho \cdot \frac{V}{A} \cdot \frac{\mathrm{d} c}{\mathrm{~d} t} \cdot \frac{273}{273+T}$

where $J$ is the flux $\left(\mathrm{mg} \mathrm{m}^{-2} \mathrm{~h}^{-1}\right), \rho$ is the gas density of GHGs, and $\rho=P / R T\left(\mathrm{~g} \mathrm{~m}^{-3}\right), P$ is air pressure, $T$ is the air temperature inside the chamber, $R$ is the gas constant, $V$ is the volume of the sampling chamber $\left(\mathrm{m}^{3}\right), A$ is the bottom area of the sampling chamber $\left(\mathrm{m}^{2}\right)$, and $\mathrm{d} c / \mathrm{d} t$ is the ratio of change in the gas concentration $(c)$ inside the chamber per unit time $(t)$ during the sampling period $\left(\mathrm{m}^{3} \mathrm{~m}^{-3} \mathrm{~h}^{-1}\right) . T$ is the air temperature $\left({ }^{\circ} \mathrm{C}\right)$.

The relationship between ST and soil $\mathrm{CO}_{2}$ fluxes was modeled by the exponential equation:

$R=R_{0} e^{b T}$

where $R$ is the soil $\mathrm{CO}_{2}$ emission rate $\left(\mathrm{mg} \mathrm{m}^{-2} \mathrm{~h}^{-1}\right), T$ is the ST $\left({ }^{\circ} \mathrm{C}\right)$ at $5 \mathrm{~cm}$ depth, $R_{0}$ and $b$ are best-fitting coefficients. For each tree species, a specific exponential relation could be fitted by Eq. (2). $Q_{10}$ values were used as parameters of temperature sensitivity of soil $\mathrm{CO}_{2}$ fluxes, based on the equation:
$Q_{10}=e^{(10 b)}$

The relationship between ST and air temperature was modeled by the following equation:

$T=a T_{\mathrm{a}}+b$

where $T_{\mathrm{a}}$ is the daily air temperature $\left({ }^{\circ} \mathrm{C}\right), a$ and $b$ are bestfitting coefficients.

Annual soil $\mathrm{CO}_{2}$ fluxes were calculated as the sum of the daily soil respiration rates:

$Y=\sum 24 \times R_{0} e^{b T}$

where $Y$ is the accumulative soil $\mathrm{CO}_{2}$ flux $\left(\mathrm{Mg} \mathrm{ha}^{-1} \mathrm{yr}^{-1}\right)$.

Annual soil $\mathrm{CH}_{4}$ and $\mathrm{N}_{2} \mathrm{O}$ fluxes were determined from the accumulated emission rates between every two consecutive days of measurements by the following equation:

$Y=\sum_{i=1}^{n}\left(X_{i}+X_{i+1}\right) / 2 \times\left(t_{i+1}-t_{i}\right) \times 24$

where $Y$ is the accumulative soil $\mathrm{CH}_{4}$ or $\mathrm{N}_{2} \mathrm{O}$ flux $\left(\mathrm{kg} \mathrm{ha}^{-1} \mathrm{yr}^{-1}\right), X$ is the soil $\mathrm{CH}_{4}$ or $\mathrm{N}_{2} \mathrm{O}$ emission rate $\left(\mu \mathrm{g} \mathrm{m}^{-2} \mathrm{~h}^{-1}\right), i$ is the $i$ th measurement, the term of $\left(\mathrm{t}_{i+1}-t_{i}\right)$ is the days between two adjacent measurements, and $n$ is the total number of measurements performed.

The mean of the coefficients of variation from adjacent sampling dates was applied to the integrated flux estimate. The uncertainty around the integrated flux over the entire year was estimated from the square root of propagated error products (Peichl et al., 2010).

The overall balance of net exchanges of $\mathrm{CO}_{2}, \mathrm{CH}_{4}$, and $\mathrm{N}_{2} \mathrm{O}$ constitutes the GWP of a tree species. The global warming potential (GWP) of $\mathrm{CH}_{4}$ and $\mathrm{N}_{2} \mathrm{O}$ are 21 and 310 times that of $\mathrm{CO}_{2}$. Therefore, GWP was estimated by multiplying annual $\mathrm{CO}_{2}, \mathrm{CH}_{4}$, and $\mathrm{N}_{2} \mathrm{O}$ fluxes by 1,21 , and 310 , respectively, and summing the results (USEPA, 2012).

\subsection{Soil temperature and moisture measurements}

Alongside GHG flux measurements, gravimetric SM content was determined by collecting soil samples $(0.1 \mathrm{~kg})$ within 

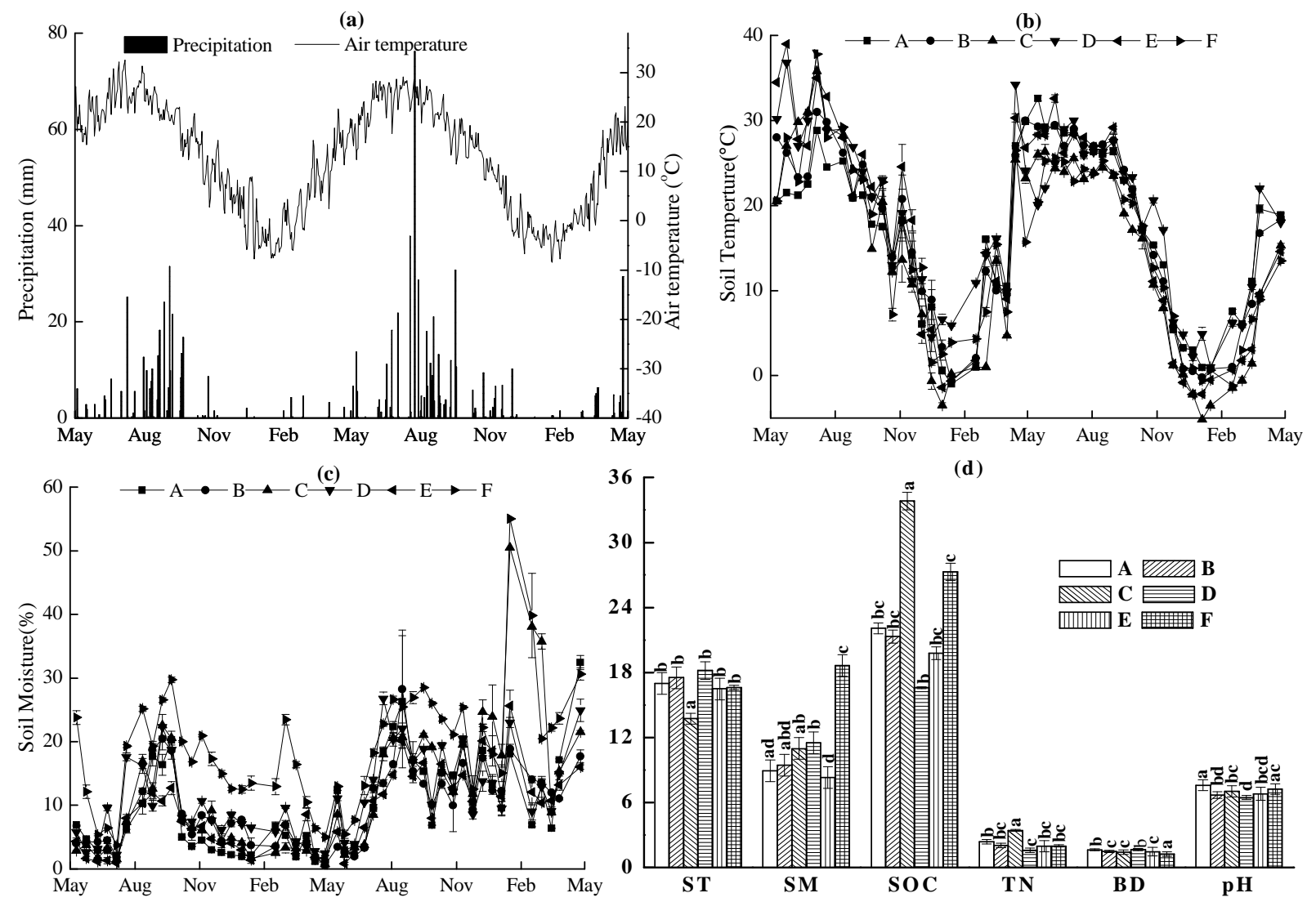

Fig. 2. Seasonal patterns of daily air temperature and precipitation (a), soil temperature at $5 \mathrm{~cm}$ depth (b), soil gravimetric moisture (c), and soil properties (d) measured in six tree species on Taihang Mountain from May 2010 to April 2012. The tree species are (A) Robinia pseudoacacia, (B) Vitex negundo var. heterophylla, (C) Leptodermis oblonga, (D) Punica granatum, (E) Ziziphus jujube, and (F) Bothriochloa ischcemum. The error bars represent standard errors $(n=3)$. ST: soil temperature $\left({ }^{\circ} \mathrm{C}\right)$, SM: soil moisture $(\%)$, SOC: soil organic carbon $\left(\times 10^{3} \mathrm{mg} \mathrm{kg}^{-1}\right), \mathrm{TN}$ : total $\mathrm{N}\left(\times 10^{3} \mathrm{mg} \mathrm{kg}^{-1}\right), \mathrm{BD}$ : bulk density $\left(\mathrm{g} \mathrm{cm}^{-3}\right), \mathrm{pH}$ : soil $\mathrm{pH}$ (in water).

$50 \mathrm{~cm}$ distance of the chambers at 0 to $10 \mathrm{~cm}$ depth. Fresh soil samples were weighed and transported to the laboratory, where they were oven-dried at $105^{\circ} \mathrm{C}$ for $24 \mathrm{~h}$ and weighed again, following which SM content was determined. ST at $5 \mathrm{~cm}$ depth was measured with a standard soil thermometer. Climatic data (daily precipitation and daily air temperature) were obtained from a weather station at the Hilly Ecosystem Experimental Station in Taihang Mountain, Chinese Academy of Sciences.

\subsection{Data analyses}

Statistical analyses were performed using the SPSS software package for Windows (Version 18.0, SPSS Inc., Chicago, Il, USA). Data sets were tested for normal distribution by the Kolmogorov-Smirnov test. The differences of soil environmental variables (ST (at $5 \mathrm{~cm}$ depth), SM $(0-10 \mathrm{~cm}$ ), SOC $(0-10 \mathrm{~cm}), \mathrm{TN}(0-10 \mathrm{~cm}), \mathrm{BD}(0-10 \mathrm{~cm})$, and $\mathrm{pH}(0-10 \mathrm{~cm}))$ among six tree species, and the impacts of season, surface litter removal, and site under different tree species on GHG fluxes were evaluated using one-way ANOVA followed by a
Tukey multiple-comparison test at $P<0.05$. A paired $t$ test was performed to examine the difference in GHG fluxes between rainy season and dry season for the same tree species. Simple linear regression was used to evaluate the relationships between soil environmental variables and mean annual GHG fluxes of each static chamber separately. The effect of ST and SM on GHG fluxes was evaluated by multiple linear regression. Stepwise regression was used to test the influence of soil environmental variables on mean annual GHG fluxes.

\section{Results}

\subsection{Environmental variables}

Precipitation over the two years ranged from 317 to $573 \mathrm{~mm}$, which was similar to the long-term average annual rainfall $(560 \mathrm{~mm})$. Precipitation showed very strong seasonality, with $77 \%$ occurring during the rainy season (June to September) (Fig. 2a). Mean annual air temperature was $12.8^{\circ} \mathrm{C}$, with monthly average temperature values ranging from $-8.4^{\circ} \mathrm{C}$ (January 2012) to $32.6^{\circ} \mathrm{C}$ (July 2010) (Fig. 2a). ST in the 
top $5 \mathrm{~cm}$ showed clear seasonal variation, with monthly low temperatures across the six tree species ranging from -5.2 to

$1.0^{\circ} \mathrm{C}$ and high temperatures ranging from 31.0 to $38.0^{\circ} \mathrm{C}$ (Fig. 2b). Gravimetric SM also varied seasonally, with lows across the six tree species ranging between 0.6 and $3.7 \%$ and highs ranging from 28.3 to $55.0 \%$ (Fig. 2c). SM data were consistent with rainfall data and were higher during the rainy season.

P. granatum had the highest ST, followed by $V$. negundo var. heterophylla, the lowest value was recorded at $L . o b$ longa, and there was significant difference between $L . o b$ longa and other five tree species $(P<0.05)$ (Fig. $2 \mathrm{~d})$. In terms of SM, B. ischcemum had the highest value (18.6\%), followed by $P$. granatum (11.5\%), and Z. jujube had the lowest value $(8.3 \%)$ (Fig. 2d). There were significantly different soil concentrations of SOC and TN $(P<0.05)$ among different tree species, with higher values at the $L$. oblonga and B. ischcemum (Fig. 2d). L. oblonga had the highest SOC concentration, followed by $B$. ischcemum and $R$. pseudoacacia, and the lowest concentration was found in P. granatum (Fig. 2d). As seen with SOC content, the higher TN contents were found at $L$. oblonga and $R$. pseudoacacia, ranging from 2368.1 to $3424.7 \mathrm{mg} \mathrm{kg}^{-1}$, while $P$. granatum had low TN content, with mean value of $1581.3 \mathrm{mg} \mathrm{kg}^{-1}$ (Fig. 2d). $P$. granatum had the highest $\mathrm{BD}$, followed by $R$. pseudoacacia and L. oblonga and B. ischcemum had the lowest value. The soil pH ranges from 6.5 to 7.6 (Fig. 2d).

\section{2 $\mathrm{CO}_{2}$ fluxes}

$\mathrm{CO}_{2}$ flux rates averaged across the $\mathrm{BS}$ and SL treatments over the two year in $R$. pseudoacacia, $V$. negundo var. heterophylla, L. oblonga, P. granatum, Z. jujube, and B. ischcemum were on average (mean \pm S.E.) $285.6 \pm 31.1$, $203.9 \pm 25.9,119.7 \pm 13.1,212.3 \pm 26.1,329.2 \pm 41.6$, and $171.9 \pm 16.3 \mathrm{mg} \mathrm{CO}_{2} \mathrm{~m}^{-2} \mathrm{~h}^{-1}$, respectively (Table 3). There were significant differences in annual mean $\mathrm{CO}_{2}$ fluxes among tree species (Tables 3 and 4). $\mathrm{CO}_{2}$ emissions from the six tree species were significantly higher during the rainy season $(P<0.01)$ (Fig. 3, Table 3). The seasonality of $\mathrm{CO}_{2}$ emissions was more pronounced in the control (SL) treatment than in the litter exclusion (BS) treatment across the six tree species (Fig. 3). Removal of the litter layer reduced soil $\mathrm{CO}_{2}$ emissions from all tree species (Fig. 3, Table 4). $\mathrm{CO}_{2}$ emissions were significantly higher in the SL treatment than in the BS treatment $(P<0.01)$ (Fig. 3, Table 4). $\mathrm{CO}_{2}$ emissions from all tree species over the two years showed a significant positive correlation with ST $(P<0.01)$, SM $(P<0.01)$, and their interaction $(P<0.01)$ (Table 5). $\mathrm{CO}_{2}$ fluxes were significantly positively correlated with SOC and TN when $B$. ischcemum $(P>0.05)$ were excluded, and negatively correlated with BD in $V$. negundo var. heterophylla $(P<0.05)$, L. oblonga $(P<0.01)$, P. granatum $(P<0.01)$, and $B$. ischcemum $(P<0.01)$, while positively correlated with BD in $Z$. jujube $(P<0.01)$ (Table 5). The stepwise regression analysis showed that a combination of ST, SM, and $\mathrm{BD}$ could best predict $\mathrm{CO}_{2}$ emissions from $R$. pseudoacacia (Table 6), SM and BD, and SM and TN could explain the variation in $\mathrm{CO}_{2}$ fluxes from $L$. oblonga and $B$. ischcemum observed at a significant level, respectively (Table 6), SOC showed a significant positive correlation with $\mathrm{CO}_{2}$ fluxes from V. negundo var. heterophylla and P. granatum, and BD was the most important factor for $\mathrm{CO}_{2}$ emissions from Z. jujube (Table 6). With the exception of R. pseudoacacia $(P<0.01)$, $\mathrm{pH}$ did not show any correlation with the $\mathrm{CO}_{2}$ fluxes $(P>0.05)$ (Table 5).

\section{3 $\mathrm{CH}_{4}$ fluxes}

$\mathrm{CH}_{4}$ flux rates averaged across the BS and SL treatments over the two year from $R$. pseudoacacia, $V$. negundo var. heterophylla, L. oblonga, P. granatum, Z. jujube, and B. ischcemum were on average $\quad($ mean \pm S.E. $) \quad-151.9 \pm 20.2, \quad-101.3 \pm 21.7$, $-215.1 \pm 74.3, \quad-131.5 \pm 30.0, \quad-95.0 \pm 15.9, \quad$ and $-99.1 \pm 15.8 \mu \mathrm{g} \mathrm{CH}_{4} \mathrm{~m}^{-2} \mathrm{~h}^{-1}$, respectively (Table 3). For all tree species, soils acted as sinks for atmospheric $\mathrm{CH}_{4}$ (Table 7). Differences in annual mean $\mathrm{CH}_{4}$ fluxes among tree species were not significant $(P>0.05)$ (Table 4). There were no significant seasonal differences in $\mathrm{CH}_{4}$ fluxes over the two years for any species (Fig. 4, Tables 3 and 4). Litter removal significantly reduced $\mathrm{CH}_{4}$ uptakes $(P<0.01)$ (Table 4). With the exception of L. oblonga $(P<0.01), \mathrm{CH}_{4}$ flux rates from all tree species over the two years showed no significant correlation with ST (Table 5). $\mathrm{CH}_{4}$ flux rates over the two years showed no significant correlation with SM when $R$. pseudoacacia $(P<0.01)$ were excluded (Table 5$)$. $\mathrm{CH}_{4}$ fluxes showed no correlation with SOC $(P>0.05)$, TN $(P>0.05), \mathrm{BD}(P>0.05)$ or $\mathrm{pH}(P>0.05)$ (Table 5$)$. However, the stepwise regression analysis showed that a combination of SM, TN and BD, and ST and SOC could best predict $\mathrm{CH}_{4}$ fluxes from L. oblonga and B. ischcemum, respectively (Table 6).

\section{$3.4 \quad \mathrm{~N}_{2} \mathrm{O}$ fluxes}

$\mathrm{N}_{2} \mathrm{O}$ flux rates averaged across the BS and SL treatments over the two year from $R$. pseudoacacia, $V$. negundo var. heterophylla, L. oblonga, P. granatum, Z. jujube, and B. ischcemum were on average (mean \pm S.E.) $-16.8 \pm 8.3$, $-10.0 \pm 5.6,-34.4 \pm 12.0,-49.5 \pm 22.1,25.5 \pm 10.0$, and $0.6 \pm 0.3 \mu \mathrm{g} \mathrm{N} \mathrm{N}_{2} \mathrm{O} \mathrm{m}^{-2} \mathrm{~h}^{-1}$, respectively (Table 3). Differences in annual mean $\mathrm{N}_{2} \mathrm{O}$ emissions between $L$. oblonga $(P<0.01)$, $P$. granatum $(P<0.01)$, and $Z$. jujube, $P$. granatum $(P<0.05)$ and $B$. ischcemum were significant (Tables 3 and 4). Seasonal shifts in $\mathrm{N}_{2} \mathrm{O}$ emissions were found to be significant (Fig. 5). $\mathrm{N}_{2} \mathrm{O}$ fluxes mainly fluctuated around zero during the dry season (Fig. 5, Table 3). However, the rain initially triggered a positive $\mathrm{N}_{2} \mathrm{O}$ flux, but overall, fluxes were negative during the rainy season (Fig. 5). For all tree species 
Table 3. Effects of season, tree species on GHG fluxes, soil temperature, and soil moisture (mean \pm S.E.) of six tree species.

\begin{tabular}{|c|c|c|c|c|c|c|}
\hline & & $\begin{array}{c}\mathrm{CO}_{2} \text { flux } \\
\left(\mathrm{mg} \mathrm{CO}_{2}\right. \\
\left.\mathrm{m}^{-2} \mathrm{~h}^{-1}\right)\end{array}$ & $\begin{array}{r}\mathrm{CH}_{4} \text { flux } \\
\left(\mu \mathrm{gCH}_{4}\right. \\
\left.\mathrm{m}^{-2} \mathrm{~h}^{-1}\right)\end{array}$ & $\begin{array}{l}\mathrm{N}_{2} \mathrm{O} \text { flux } \\
\left(\mu \mathrm{g} \mathrm{N}_{2} \mathrm{O}\right. \\
\left.\mathrm{m}^{-2} \mathrm{~h}^{-1}\right)\end{array}$ & $\begin{array}{r}\text { Soil } \\
\text { temperature } \\
\left({ }^{\circ} \mathrm{C}\right)\end{array}$ & $\begin{array}{r}\text { Soil } \\
\text { moisture } \\
(\%)\end{array}$ \\
\hline \multirow{3}{*}{$\begin{array}{l}\text { Robinia } \\
\text { pseudoacacia }\end{array}$} & Rainy season & $541.3 \pm 61.2^{\mathrm{a}}$ & $-177.4 \pm 38.9$ & $-42.6 \pm 22.0^{b}$ & $24.6 \pm 0.8^{\mathrm{a}}$ & $11.9 \pm 1.9$ \\
\hline & Dry season & $139.7 \pm 16.2^{\mathrm{a}}$ & $-139.5 \pm 23.3$ & $-2.6 \pm 1.8^{\mathrm{b}}$ & $12.8 \pm 1.7^{\mathrm{a}}$ & $8.7 \pm 1.3$ \\
\hline & Mean & $285.6 \pm 31.1 \mathrm{a}$ & $-151.9 \pm 20.2$ & $-16.8 \pm 8.3$ & $17.0 \pm 1.4$ & $9.8 \pm 1.1$ \\
\hline \multirow{3}{*}{$\begin{array}{l}\text { Vitex negundo var. } \\
\text { heterophylla }\end{array}$} & Rainy season & $378.7 \pm 51.6^{\mathrm{a}}$ & $-102.0 \pm 52.2$ & $-45.8 \pm 24.5^{b}$ & $25.9 \pm 0.8^{\mathrm{a}}$ & $11.9 \pm 1.8$ \\
\hline & Dry season & $95.7 \pm 17.7^{\mathrm{a}}$ & $-100.9 \pm 17.8$ & $9.6 \pm 8.6^{b}$ & $12.7 \pm 1.8^{\mathrm{a}}$ & $8.6 \pm 0.9$ \\
\hline & Mean & $203.9 \pm 25.9 \mathrm{ab}$ & $-101.3 \pm 21.7 \mathrm{a}$ & $-10.0 \pm 5.6$ & $17.4 \pm 1.5$ & $9.8 \pm 0.9$ \\
\hline \multirow{3}{*}{$\begin{array}{l}\text { Leptodermis } \\
\text { oblonga }\end{array}$} & Rainy season & $206.9 \pm 25.9^{\mathrm{a}}$ & $-184.0 \pm 49.5$ & $-86.4 \pm 30.0^{\mathrm{a}}$ & $24.8 \pm 1.2^{\mathrm{a}}$ & $12.9 \pm 1.9$ \\
\hline & Dry season & $66.8 \pm 9.8^{\mathrm{a}}$ & $-232.1 \pm 112.2$ & $-5.8 \pm 4.5^{\mathrm{a}}$ & $10.8 \pm 2.7^{\mathrm{a}}$ & $11.0 \pm 1.8$ \\
\hline & Mean & $119.7 \pm 13.1 \mathrm{abc}$ & $-215.1 \pm 74.3 \mathrm{ab}$ & $-34.4 \pm 12.0 \mathrm{a}$ & $15.7 \pm 2.1$ & $11.7 \pm 1.3$ \\
\hline \multirow{3}{*}{ Punica granatum } & Rainy season & $402.0 \pm 57.3^{\mathrm{a}}$ & $-190.5 \pm 68.8$ & $-77.0 \pm 27.5$ & $27.1 \pm 0.9^{\mathrm{a}}$ & $16.0 \pm 2.2^{\mathrm{a}}$ \\
\hline & Dry season & $108.3 \pm 13.1^{\mathrm{a}}$ & $-101.9 \pm 28.7$ & $-34.3 \pm 13.7$ & $14.5 \pm 1.7^{\mathrm{a}}$ & $9.9 \pm 1.1^{\mathrm{a}}$ \\
\hline & Mean & $212.3 \pm 26.1 \mathrm{~cd}$ & $-131.5 \pm 30$ & $-49.5 \pm 22.1 b$ & $19.0 \pm 1.4$ & $12.0 \pm 1.1$ \\
\hline \multirow{3}{*}{ Ziziphus jujube } & Rainy season & $689.0 \pm 86.5^{\mathrm{a}}$ & $-105.9 \pm 37.0$ & $54.9 \pm 27.5^{b}$ & $27.3 \pm 0.9^{\mathrm{a}}$ & $9.6 \pm 1.4$ \\
\hline & Dry season & $137.3 \pm 14.1^{\mathrm{a}}$ & $-89.4 \pm 15.1$ & $9.8 \pm 3.6^{\mathrm{b}}$ & $12.0 \pm 2.2^{\mathrm{a}}$ & $8.7 \pm 1.1$ \\
\hline & Mean & $329.2 \pm 41.6 \mathrm{bcde}$ & $-95.0 \pm 15.9 b c$ & $25.5 \pm 10.0 \mathrm{abc}$ & $17.4 \pm 1.8$ & $9.0 \pm 0.9$ \\
\hline \multirow{3}{*}{$\begin{array}{l}\text { Bothriochloa } \\
\text { ischcemum }\end{array}$} & Rainy season & $322.4 \pm 28.7^{\mathrm{a}}$ & $-79.1 \pm 19.0$ & $51.5 \pm 14.8$ & $25.1 \pm 1.1^{\mathrm{a}}$ & $19.5 \pm 2.2$ \\
\hline & Dry season & $89.4 \pm 9.0^{\mathrm{a}}$ & $-110.0 \pm 22.2$ & $-27.3 \pm 9.0$ & $10.7 \pm 1.5^{\mathrm{a}}$ & $19.1 \pm 1.9$ \\
\hline & Mean & $171.9 \pm 16.3 \mathrm{ae}$ & $-99.1 \pm 15.8 b d$ & $0.6 \pm 0.3 \mathrm{bd}$ & $15.8 \pm 1.5$ & $19.3 \pm 1.4$ \\
\hline
\end{tabular}

Note: S.E. stands for standard error.

a Along the columns denote significance of the impacts of season on GHG fluxes, soil temperature, and soil moisture, Significant impact at $\alpha<0.01$;

b Significant impact at a $<0.05$.

The values within a column that are followed by the same letter are significantly different at an alpha $=0.05$.

Table 4. Significance of the impacts of tree species, litter removal treatment, season, and their interactions on GHG fluxes.

\begin{tabular}{llll}
\hline & $\begin{array}{l}\mathrm{CO}_{2} \\
\text { flux }\end{array}$ & $\begin{array}{l}\mathrm{CH}_{4} \\
\text { flux }\end{array}$ & $\begin{array}{l}\mathrm{N}_{2} \mathrm{O} \\
\text { flux }\end{array}$ \\
\hline Tree species & $0.000^{*}$ & 0.230 & $0.000^{*}$ \\
Treatment & $0.000^{*}$ & $0.000^{*}$ & 0.505 \\
Season & $0.000^{*}$ & 0.712 & 0.219 \\
Tree species $\times$ treatment & $0.002^{*}$ & 0.912 & $0.000^{*}$ \\
Tree species $\times$ season & $0.000^{*}$ & 0.841 & $0.001^{*}$ \\
Treatment $\times$ season & $0.001^{*}$ & 0.427 & 0.801 \\
Tree species $\times$ treatment $\times$ season & 0.056 & 0.822 & $0.004^{*}$ \\
\hline
\end{tabular}

* Significant impact at a $<0.01$.

apart from Z. jujube, soils acted as sinks for atmospheric $\mathrm{N}_{2} \mathrm{O}$ (Table 7). Litter removal did not have an important effect on $\mathrm{N}_{2} \mathrm{O}$ emissions $(P>0.05)$ (Table 4$) . \mathrm{N}_{2} \mathrm{O}$ flux rates were significantly negatively correlated with ST $(P<0.05)$ in $R$. pseudoacacia and SM $(P<0.05)$ in $L$. oblonga (Table 5 ). $\mathrm{N}_{2} \mathrm{O}$ fluxes were significantly positively correlated with SOC and TN when B. ischcemum $(P>0.05)$ were excluded (Table 5). $\mathrm{N}_{2} \mathrm{O}$ fluxes were significantly negatively correlated with BD when $R$. pseudoacacia $(P>0.05)$ and $V$. negundo var. heterophylla $(P>0.05)$ were excluded (Table 5). The stepwise regression analysis showed that a combination of SOC and TN, and SM and TN could best predict $\mathrm{N}_{2} \mathrm{O}$ fluxes from $V$. negundo var. heterophylla and B. ischcemum, respectively, SOC was the most important factor for $\mathrm{N}_{2} \mathrm{O}$ emissions from $R$. pseudoacacia, $P$. granatum and $Z$. jujube, and $\mathrm{N}_{2} \mathrm{O}$ fluxes from $L$. oblonga were significantly negatively correlated with $\mathrm{BD}$ (Table 6). $\mathrm{N}_{2} \mathrm{O}$ fluxes were significantly positively correlated with $\mathrm{pH}(P<0.01)$ in $R$. pseudoacacia (Table 5).

\subsection{Global warming potential}

The GWPs of managed vegetation $R$. pseudoacacia, $P$. granatum, and $Z$. jujube were high (16.7-25.6 $\mathrm{Mg} \mathrm{CO}_{2}$ C equivalent ha ${ }^{-1} \mathrm{yr}^{-1}$ ) compared to naturally regenerated vegetation $V$. negundo var. heterophylla, $L$. oblonga, and B. ischcemum (8.4-15.8 $\mathrm{Mg} \mathrm{CO}_{2}$-C equivalent ha ${ }^{-1} \mathrm{yr}^{-1}$ ) (Table 7).

\section{Discussion}

\section{1 $\mathrm{CO}_{2}$}

We found soil $\mathrm{CO}_{2}$ emissions from managed forest plots to be higher than those from natural forest areas, similar to 
Table 5. Linear regressions for the relationship between soil properties and GHG fluxes.

\begin{tabular}{|c|c|c|c|c|}
\hline & & $\begin{array}{c}\mathrm{CO}_{2} \text { flux } \\
\left(\mathrm{mg} \mathrm{CO}_{2}\right. \\
\left.\mathrm{m}^{-2} \mathrm{~h}^{-1}\right)\end{array}$ & $\begin{array}{c}\mathrm{CH}_{4} \text { flux } \\
\left(\mu \mathrm{gCH}_{4}\right. \\
\left.\mathrm{m}^{-2} \mathrm{~h}^{-1}\right)\end{array}$ & $\begin{array}{l}\mathrm{N}_{2} \mathrm{O} \text { flux } \\
\left(\mu \mathrm{g} \mathrm{N}_{2} \mathrm{O}\right. \\
\left.\mathrm{m}^{-2} \mathrm{~h}^{-1}\right)\end{array}$ \\
\hline \multirow{7}{*}{ Robinia pseudoacacia } & Soil temperature & $0.545^{\mathrm{a}}$ & -0.032 & $-0.217^{b}$ \\
\hline & Soil moisture & $0.566^{\mathrm{a}}$ & $-0.268^{\mathrm{a}}$ & 0.020 \\
\hline & Soil temperature $\times$ soil moisture & $0.764^{\mathrm{a}}$ & 0.268 & 0.219 \\
\hline & Soil organic carbon & $0.861^{\mathrm{a}}$ & 0.252 & $0.860^{\mathrm{a}}$ \\
\hline & Total N & $0.654^{\mathrm{b}}$ & 0.293 & $0.642^{\mathrm{b}}$ \\
\hline & Soil bulk density & 0.294 & 0.500 & -0.429 \\
\hline & Soil pH & $-0.844^{\mathrm{a}}$ & 0.053 & $0.910^{\mathrm{a}}$ \\
\hline \multirow{7}{*}{ Vitex negundo var. heterophylla } & Soil temperature & $0.482^{\mathrm{a}}$ & 0.049 & -0.187 \\
\hline & Soil moisture & $0.510^{\mathrm{a}}$ & -0.084 & -0.035 \\
\hline & Soil temperature $\times$ soil moisture & $0.731^{\mathrm{a}}$ & 0.093 & 0.195 \\
\hline & Soil organic carbon & $0.829^{\mathrm{a}}$ & -0.023 & $0.916^{\mathrm{a}}$ \\
\hline & Total N & $0.729^{\mathrm{a}}$ & -0.004 & $0.800^{\mathrm{a}}$ \\
\hline & Soil bulk density & $-0.548^{\mathrm{b}}$ & 0.280 & -0.566 \\
\hline & Soil pH & -0.157 & 0.400 & 0.228 \\
\hline \multirow{7}{*}{ Leptodermis oblonga } & Soil temperature & $0.472^{\mathrm{a}}$ & $-0.418^{\mathrm{a}}$ & -0.060 \\
\hline & Soil moisture & $0.274^{\mathrm{a}}$ & -0.105 & $-0.205^{\mathrm{b}}$ \\
\hline & Soil temperature $\times$ soil moisture & $0.587^{\mathrm{a}}$ & $0.461^{\mathrm{a}}$ & 0.229 \\
\hline & Soil organic carbon & $0.729^{\mathrm{a}}$ & 0.362 & $0.804^{\mathrm{a}}$ \\
\hline & Total N & $0.683^{\mathrm{b}}$ & 0.536 & $0.712^{\mathrm{a}}$ \\
\hline & Soil bulk density & $-0.701^{\mathrm{a}}$ & -0.321 & $-0.900^{\mathrm{a}}$ \\
\hline & Soil pH & 0.090 & 0.342 & 0.025 \\
\hline \multirow{7}{*}{ Punica granatum } & Soil temperature & $0.418^{\mathrm{a}}$ & -0.036 & -0.114 \\
\hline & Soil moisture & $0.534^{\mathrm{a}}$ & -0.193 & 0.080 \\
\hline & Soil temperature $\times$ soil moisture & $0.672^{\mathrm{a}}$ & 0.195 & 0.141 \\
\hline & Soil organic carbon & $0.973^{\mathrm{a}}$ & 0.206 & $0.953^{\mathrm{a}}$ \\
\hline & Total N & $0.730^{\mathrm{a}}$ & 0.342 & $0.821^{\mathrm{a}}$ \\
\hline & Soil bulk density & $-0.721^{\mathrm{a}}$ & -0.146 & $-0.936^{\mathrm{a}}$ \\
\hline & Soil pH & -0.017 & -0.260 & -0.078 \\
\hline \multirow{7}{*}{ Ziziphus jujube } & Soil temperature & $0.498^{\mathrm{a}}$ & -0.010 & 0.167 \\
\hline & Soil moisture & $0.328^{\mathrm{a}}$ & $-0.266^{\mathrm{b}}$ & 0.011 \\
\hline & Soil temperature $\times$ soil moisture & $0.690^{\mathrm{a}}$ & $0.275^{\mathrm{b}}$ & 0.177 \\
\hline & Soil organic carbon & $0.903^{\mathrm{a}}$ & -0.095 & $0.891^{\mathrm{a}}$ \\
\hline & Total N & $0.639^{\mathrm{b}}$ & -0.063 & $0.851^{\mathrm{a}}$ \\
\hline & Soil bulk density & $0.546^{\mathrm{a}}$ & 0.131 & $-0.862^{\mathrm{a}}$ \\
\hline & Soil pH & -0.467 & -0.375 & 0.317 \\
\hline \multirow{7}{*}{ Bothriochloa ischcemum } & Soil temperature & $0.532^{\mathrm{a}}$ & 0.106 & 0.118 \\
\hline & Soil moisture & $0.313^{\mathrm{a}}$ & -0.041 & 0.006 \\
\hline & Soil temperature $\times$ soil moisture & $0.716^{\mathrm{a}}$ & 0.107 & 0.125 \\
\hline & Soil organic carbon & 0.437 & -0.467 & 0.378 \\
\hline & Total N & 0.448 & -0.543 & 0.405 \\
\hline & Soil bulk density & $-0.663^{\mathrm{a}}$ & 0.042 & $-0.863^{\mathrm{a}}$ \\
\hline & Soil pH & 0.183 & -0.568 & -0.200 \\
\hline
\end{tabular}

a Significant correlation at a $<0.01$.

b Significant correlation at a $<0.05$.

the observations of Iqbal et al. (2009) who reported higher $\mathrm{CO}_{2}$ fluxes from orchards than from woodland soil in midsubtropical red soil of southern China. Differences in soil fluxes of greenhouse gases between natural and managed forests may be attributed to variations in SOC (Young et al., 2005), soil microclimate (Raich and Tufekcioglu, 2000), and below- and above-ground plant metabolism (Campbell and Law, 2005). Iqbal et al. (2009) attributed the higher $\mathrm{CO}_{2}$ flux 
Table 6. Stepwise regressions for the relationship between soil properties and GHG fluxes.

\begin{tabular}{|c|c|c|c|c|c|c|c|}
\hline & & \multicolumn{2}{|c|}{$\mathrm{CO}_{2}$} & \multicolumn{2}{|c|}{$\mathrm{CH}_{4}$} & \multicolumn{2}{|c|}{$\mathrm{N}_{2} \mathrm{O}$} \\
\hline & & $r^{\mathrm{a}}$ & $p^{\mathrm{b}}$ & $r$ & $p$ & $r$ & $p$ \\
\hline \multirow{5}{*}{ Robinia pseudoacacia } & Soil temperature & 0.428 & 0.021 & & & & \\
\hline & Soil moisture & 0.530 & 0.007 & & & & \\
\hline & Soil bulk density & 0.269 & 0.000 & & & & \\
\hline & Soil pH & - & & & & -0.874 & 0.000 \\
\hline & Overall model $^{\mathrm{c}}$ & & 0.000 & - & - & & 0.000 \\
\hline \multirow{3}{*}{ Vitex negundo var. heterophylla } & Soil organic carbon & 0.950 & 0.000 & & & 1.819 & 0.001 \\
\hline & Total N & & & & & 0.942 & 0.023 \\
\hline & Overall model & & 0.001 & - & - & & 0.000 \\
\hline \multirow{4}{*}{ Leptodermis oblonga } & Soil moisture & 0.533 & 0.004 & -1.338 & 0.002 & & \\
\hline & Total N & & & 0.650 & 0.029 & & \\
\hline & Soil bulk density & -0.482 & 0.006 & -1.319 & 0.004 & -0.900 & 0.000 \\
\hline & Overall model & & 0.000 & & 0.003 & & 0.000 \\
\hline \multirow{2}{*}{ Punica granatum } & Soil organic carbon & 0.973 & 0.000 & & & 0.953 & 0.000 \\
\hline & Overall model & & 0.000 & - & - & & 0.000 \\
\hline \multirow{3}{*}{ Ziziphus jujube } & Soil organic carbon & & & & & 0.891 & 0.000 \\
\hline & Soil bulk density & 0.963 & 0.000 & & & & \\
\hline & Overall model & & 0.000 & - & - & & 0.000 \\
\hline \multirow{5}{*}{ Bothriochloa ischcemum } & Soil temperature & & & 0.699 & 0.005 & & \\
\hline & Soil moisture & 0.809 & 0.000 & & & 0.898 & 0.000 \\
\hline & Soil organic carbon & & & -0.588 & 0.012 & & \\
\hline & Total N & 0.324 & 0.040 & & & 0.267 & 0.006 \\
\hline & Overall model & & 0.000 & & 0.005 & & 0.000 \\
\hline
\end{tabular}

a The partial regression coefficient $(r)$ value in the stepwise regression.

$\mathrm{b}$ The partial $p$ value for the specific factor.

$\mathrm{c}$ The statistics for the regression model combining all factors that were significant at $p<0.01$.

Table 7. Effect of tree species on global warming potential (GWP) and contribution of $\mathrm{CO}_{2}, \mathrm{CH}_{4}$, and $\mathrm{N}_{2} \mathrm{O}$ to GWP.

\begin{tabular}{|c|c|c|c|c|}
\hline \multirow[t]{2}{*}{ Tree species } & \multirow[t]{2}{*}{$\begin{array}{c}\text { GWP } \\
\mathrm{Mg} \mathrm{CO}_{2}-\mathrm{C} \\
\text { eq. } \text { ha }^{-1} \mathrm{yr}^{-1}\end{array}$} & \multicolumn{3}{|c|}{$\begin{array}{l}\text { Percent of } \\
\text { total contribution } \\
\text { to GWP }\end{array}$} \\
\hline & & $\mathrm{CO}_{2}$ & $\mathrm{CH}_{4}$ & $\mathrm{~N}_{2} \mathrm{O}$ \\
\hline Robinia pseudoacacia & $22.1 \pm 0.6$ & 103.1 & -1.2 & -1.9 \\
\hline Vitex negundo var. heterophylla & $15.8 \pm 6.5$ & 103.7 & -1.1 & -2.6 \\
\hline Leptodermis oblonga & $8.4 \pm 0.5$ & 115.2 & -3.6 & -11.7 \\
\hline Punica granatum & $16.7 \pm 1.9$ & 107.5 & -1.4 & -6.1 \\
\hline Ziziphus jujube & $25.6 \pm 5.1$ & 98.4 & -0.7 & 2.2 \\
\hline Bothriochloa ischcemum & $14.6 \pm 1.8$ & 101.6 & -1.3 & -0.3 \\
\hline
\end{tabular}

from orchards primarily to the change in the quality of the substrate (the substance on which an enzyme acts) as compared to woodland, which had the most resistant and least active carbon pool. In this study, R. pseudoacacia and Z. jujube had abundant gravel and higher soil macroporosity, furthermore, forest management (e.g. weeding) in Z. jujube helped to expose soil to atmosphere and increase the topsoil macroporosity, which therefore facilitated oxygen entrance into the soil and subsequently aerobic respiration, as well as the enhanced $\mathrm{CO}_{2}$ emissions (Fang et al., 1998; Chen et al., 2010).

Not surprisingly, we found seasonal changes in $\mathrm{CO}_{2}$ flux from soils to be positively correlated with ST, with maximum flux rates in the summer months, minimum rates in winter, and intermediate rates in spring and autumn (Fig. 3). Tang et al. (2006) and Liu et al. (2008) obtained similar results. As with Yan et al. (2006) and Peichl et al. (2010), removal of surface litter reduced soil respiration rates in our study by 

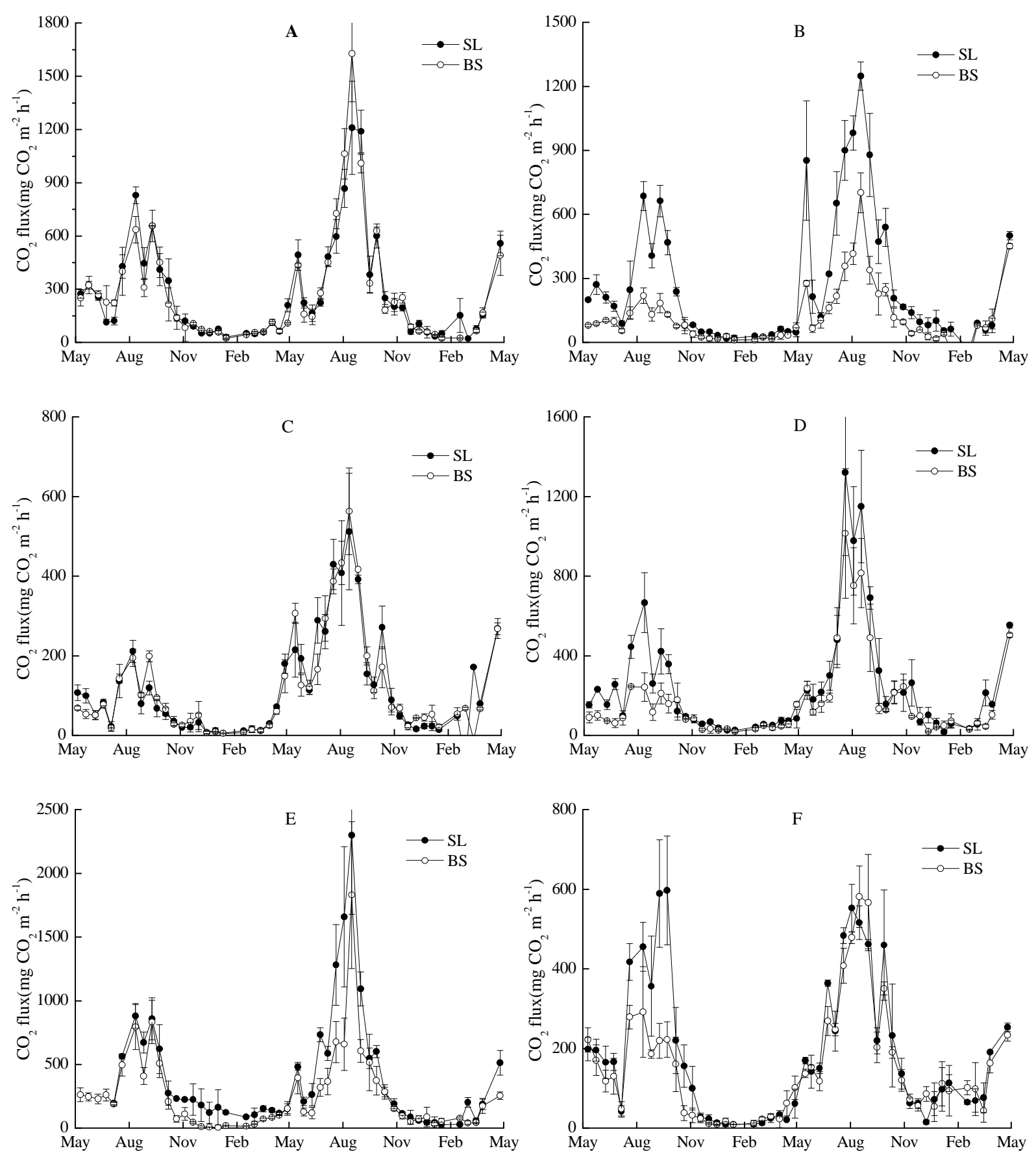

Fig. 3. Seasonal patterns of $\mathrm{CO}_{2}$ flux rates measured in six tree species on Taihang Mountain with (SL) or without (BS) surface litter from May 2010 to April 2012. The tree species are (A) Robinia pseudoacacia, (B) Vitex negundo var. heterophylla, (C) Leptodermis oblonga, (D) Punica granatum, (E) Ziziphus jujube, and (F) Bothriochloa ischcemum. The error bars represent standard errors $(n=3)$.

eliminating $\mathrm{CO}_{2}$ efflux directly from the litter (Fig. 3, Table 4).

$\mathrm{CO}_{2}$ emissions from all tree species over the two years showed a significant positive correlation with ST, SM, and their interaction (Table 5). The high to moderate $\mathrm{CO}_{2}$ flux between June and September was observed when ST and SM were high (Fig. 3). Similarly, low to negligible $\mathrm{CO}_{2}$ fluxes were observed between October and May, when ST and SM content were low (Fig. 3). Our findings are comparable to numerous field studies that have documented strong relationships between ST, $\mathrm{SM}$ and $\mathrm{CO}_{2}$ fluxes (e.g., $\mathrm{Xu}$ and Qi, 2001; Saiz et al., 2006; Tang et al., 2006; Liu et al., 2008; Iqbal et al., 2009; Iqbal et al., 2010; Peichl et al., 2010). ST and SM as the significant predictor of $\mathrm{CO}_{2}$ fluxes from $R$. pseudoacacia, 

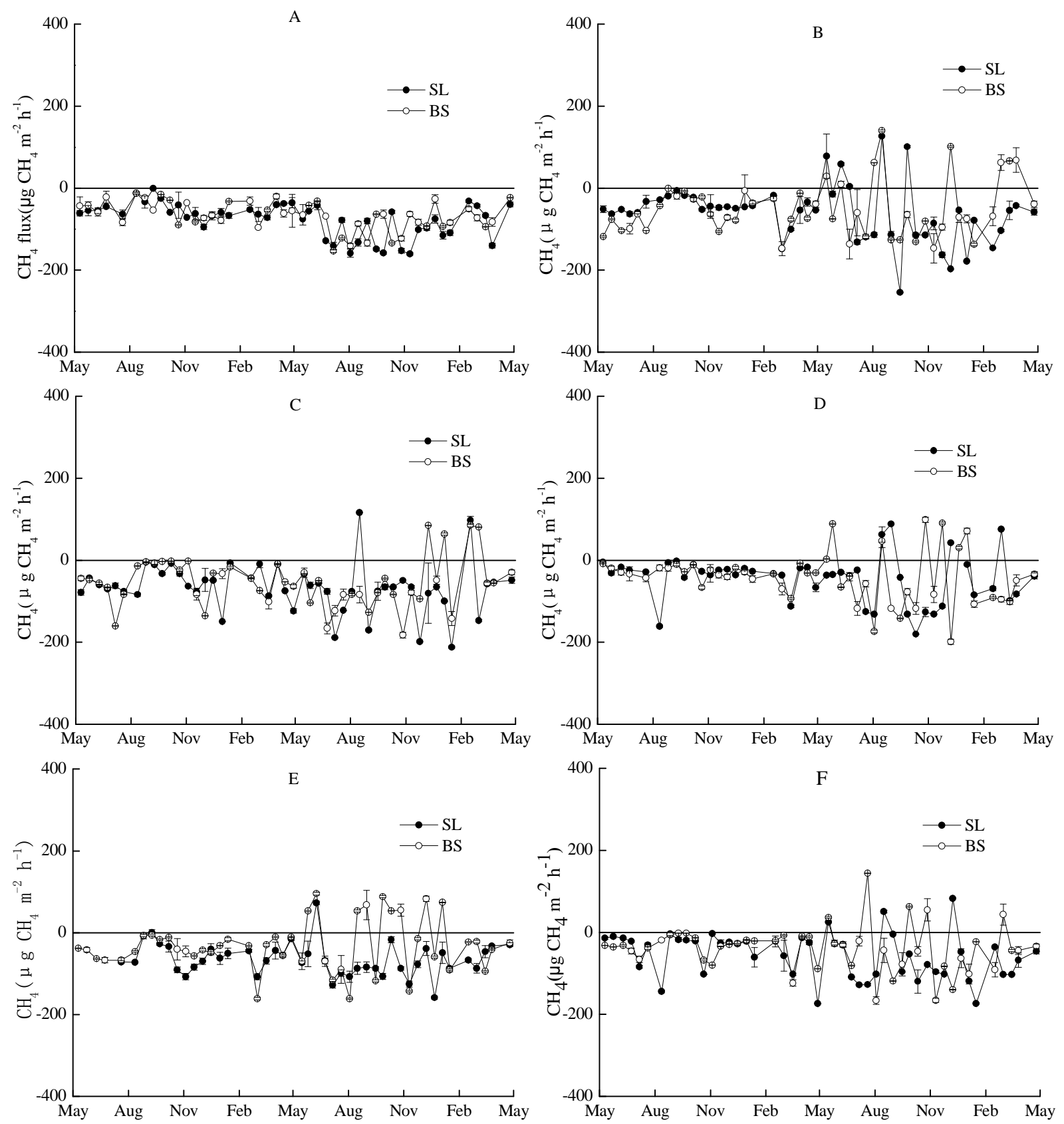

Fig. 4. Seasonal patterns of $\mathrm{CH}_{4}$ flux rates measured in six tree species on Taihang Mountain with (SL) or without (BS) surface litter from May 2010 to April 2012. The tree species are (A) Robinia pseudoacacia, (B) Vitex negundo var. heterophylla, (C) Leptodermis oblonga, (D) Punica granatum, (E) Ziziphus jujube, and (F) Bothriochloa ischcemum. The error bars represent standard errors $(n=3)$.

L. oblonga, and B. ischcemum in stepwise regression may be attributed to their sampling points were located shady. Conversely, the stepwise regression did not reveal the correlation between ST, SM and $\mathrm{CO}_{2}$ fluxes from $V$. negundo var. heterophylla, $P$. granatum, and $Z$. jujube, since the responses in $\mathrm{CO}_{2}$ emissions to ST or SM were low compared to responses to other changes.

Forest management would destroy soil aggregates and decrease inputs of soil nutrients into soil by clearing under- growth herbaceous vegetation (i.e. grasses, forbs, and herbs), all these practices led to a lower content of SOC and TN in $P$. granatum and $Z$. jujube than in natural forests (Iqbal et al., 2009). $\mathrm{CO}_{2}$ fluxes were significantly positively correlated with SOC and TN (Tables 5-6), in contrast to Shrestha et al. (2009) who found no correlation between soil $\mathrm{C}$ and $\mathrm{N}$ concentrations and $\mathrm{CO}_{2}$ fluxes. Our results showed that SOC and TN directly or indirectly affect soil $\mathrm{CO}_{2}$ emissions in a relatively stable environment (Chapman and Thurlow, 

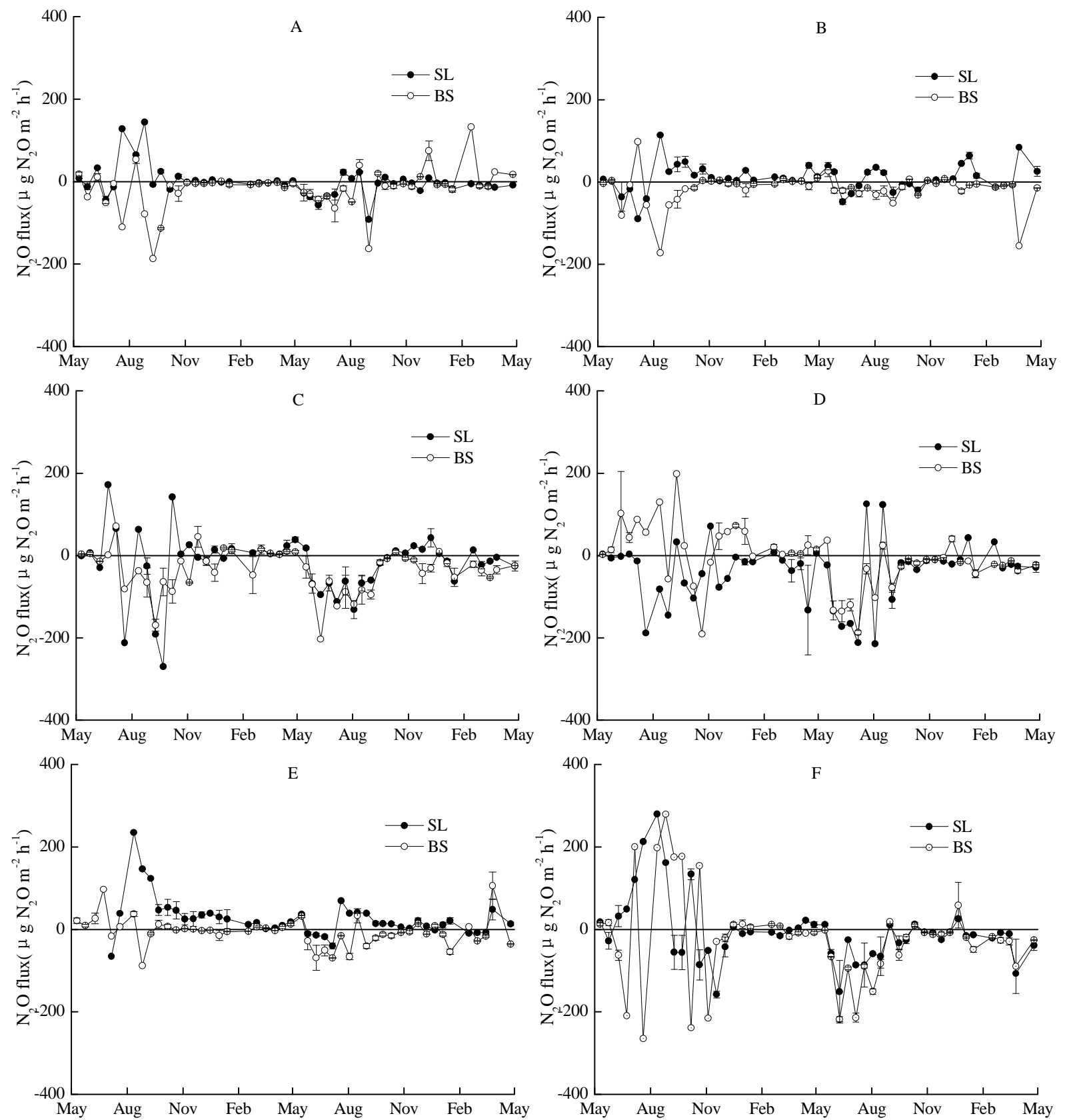

Fig. 5. Seasonal patterns of $\mathrm{N}_{2} \mathrm{O}$ flux rates measured in six tree species on Taihang Mountain with (SL) or without (BS) surface litter from May 2010 to April 2012. The tree species are (A) Robinia pseudoacacia, (B) Vitex negundo var. heterophylla, (C) Leptodermis oblonga, (D) Punica granatum, (E) Ziziphus jujube, and (F) Bothriochloa ischcemum. The error bars represent standard errors $(n=3)$.

1996). The variations in topsoil BD probably result from influences of both forest management and variability of topsoil texture. Higher topsoil BD in P. granatum could be attributed to forestry management, while $\mathrm{BD}$ on $R$. pseudoacacia and Z. jujube mainly because of abundant gravel. Positive (Shrestha et al., 2009) as well as negative (Saiz et al., 2006; Shrestha et al., 2009) effects of $\mathrm{BD}$ with soil $\mathrm{CO}_{2}$ flux have previously been reported. In our study, $\mathrm{CO}_{2}$ fluxes were sig- nificantly negatively correlated with $\mathrm{BD}$ when $R$. pseudoacacia and R. pseudoacacia were excluded (Tables 5-6).

\section{2 $\mathrm{CH}_{4}$}

$\mathrm{CH}_{4}$ fluxes in the first sampling year were negative across the six species, but fluctuated between positive and negative values when the rain started in the second sampling year. Soil $\mathrm{CH}_{4}$ fluxes during the second year of sampling were highly 
variable, and did not exhibit any well-defined pattern (Fig. 4). These findings suggest that $\mathrm{CH}_{4}$ production is switched on and off in relatively dry soils, as has been previously reported (Angel et al., 2012). With increasing precipitation in relatively dry soils, populations of methanogenic organisms increase and methanogenesis is initiated (Mayer and Conrad, 1990) because methanogenesis requires strictly anaerobic conditions (Le Mer and Roger, 2001). However, if soils become aerobic, methanogenic activity is reduced (Inubushi et al., 2003). The soils in our study acted as sinks for atmospheric $\mathrm{CH}_{4}$ on an annual basis, and the mean $\mathrm{CH}_{4}$ flux across all of our tree species $\left(-139.8 \mu \mathrm{g} \mathrm{CH}_{4} \mathrm{~m}^{-2} \mathrm{~h}^{-1}\right)$ was similar in magnitude to that determined in semi-arid zones in other studies (Wang et al., 2005; Yao et al., 2010). However, we found no significant differences in annual or seasonal $\mathrm{CH}_{4}$ fluxes among the different tree species (Table 3, Fig. 4), in agreement with several previous studies (e.g. Liu et al., 2008; Shrestha et al., 2009; Christiansen and Gundersen, 2011). In contrast, Degelmann et al. (2009) found coniferous forest soils consume less $\mathrm{CH}_{4}$ than deciduous forest soils.

$\mathrm{CH}_{4}$ flux is influenced by soil properties, such as soil diffusivity, $\mathrm{pH}, \mathrm{BD}$, and $\mathrm{SOC}$, has been reported in numerous studies (Verchot et al., 2000; Bodelier and Laanbroekb, 2004; Merino et al., 2004), but Shrestha et al. (2009) and our study did not observe any response of $\mathrm{CH}_{4}$ fluxes to single environment factor (Table 5). However, stepwise regression analysis showed that a combination of $\mathrm{SM}, \mathrm{TN}$ and $\mathrm{BD}$, and $\mathrm{ST}$ and SOC could best predict $\mathrm{CH}_{4}$ fluxes from L. oblonga and B. ischcemum, respectively (Table 6). This suggested that the relationship between single environmental factor and $\mathrm{CH}_{4}$ fluxes to be of limited significance, with the combination of multiple environment factors attaining more importance. The lack of dependence of $\mathrm{CH}_{4}$ fluxes from $R$. pseudoacacia, $V$. negundo var. heterophylla, $P$. granatum, and $Z$. jujube on environmental factors suggested that environmental factors other than those measured in this study may have exerted a greater impact on soil $\mathrm{CH}_{4}$ fluxes, or that insufficient samples were collected to fully capture the higher spatial and temporal variability of these parameters (Tang et al., 2006; Vincent et al., 2006).

\section{$\begin{array}{ll}4.3 & \mathrm{~N}_{2} \mathrm{O}\end{array}$}

Average $\mathrm{N}_{2} \mathrm{O}$ emission rates and total annual emissions recorded in our study were similar to those reported by Yao et al. (2010) for semi-arid zones. $\mathrm{N}_{2} \mathrm{O}$ fluxes were low during winter and high through spring, peaking in summer. Soil served as a $\mathrm{N}_{2} \mathrm{O}$ sink during the drought period, quickly becoming a source of atmospheric $\mathrm{N}_{2} \mathrm{O}$ when the rain began. Soil water status thus appear to be important driving factors for $\mathrm{N}_{2} \mathrm{O}$ capture (Goldberg and Gebauer, 2009; Peichl et al., 2010; Gundersen et al., 2012). Forest soils serving as sinks for atmospheric $\mathrm{N}_{2} \mathrm{O}$ have been reported across a broad spectrum of studies (Chapuis-Lardy et al., 2007; Kellman and Kavanaugh, 2008; Peichl et al., 2010; Eickenscheidt and
Brumme, 2012; Inclán et al., 2012; Ma et al., 2012; Stewart et al., 2012). Rosenkranz et al. (2006) pointed out that the negative $\mathrm{N}_{2} \mathrm{O}$ fluxes were mainly due to very low $\mathrm{N}$ availability and high soil $\mathrm{C}$ content. They considered aerobic denitrification by heterotrophic nitrifiers as a possible pathway, denitrifying bacteria might use atmospheric $\mathrm{N}_{2} \mathrm{O}$ as an alternative electron acceptor to nitrate when the latter was in short supply. Moreover, Inclán et al. (2012) demonstrated that $\mathrm{N}_{2} \mathrm{O}$ sink was possibly attributed to high total dissolved organic carbon content and high SM, combined with low levels of $\mathrm{SM}$ and nitrogen. However, $\mathrm{N}_{2} \mathrm{O}$ sinks have often been overlooked and the driving factors for these sinks are poorly understood (Goldberg and Gebauer, 2009; Stewart et al., 2012).

$\mathrm{N}_{2} \mathrm{O}$ fluxes differed significantly among plant species of L. oblonga, P. granatum, Z. jujube, and B. ischcemum (Table 3). In general, the annual $\mathrm{N}_{2} \mathrm{O}$ fluxes differed significantly between species, similar to the results of Shrestha et al. (2009). It is very likely that the differences between $\mathrm{N}_{2} \mathrm{O}$ fluxes from different tree species can be explained by differences in soil properties. SOC and TN were considered as part of the explanation for these differences as reasoned by Beauchamp (1997) and Dobbie et al. (1999). Annual $\mathrm{N}_{2} \mathrm{O}$ fluxes were significantly positively correlated with SOC and TN (Table 5). Stepwise regression analysis showed that SOC could explain the variation in $\mathrm{N}_{2} \mathrm{O}$ fluxes from $R$. pseudoacacia, P. granatum and Z. jujube, a combination of SOC and $\mathrm{TN}, \mathrm{SM}$ and TN could best predict $\mathrm{N}_{2} \mathrm{O}$ fluxes from $V$. negundo var. heterophylla and $B$. ischcemum, respectively (Table 6). This indicated that soil $\mathrm{N}_{2} \mathrm{O}$ fluxes were mostly limited by $\mathrm{SOC}$ and $\mathrm{TN}$, in agreement with previous studies (Nishina et al., 2009; Shrestha et al., 2009; Mapanda et al., 2010; Yao et al., 2010). One important difference between plantations and naturally regenerated forests was the development of an upper organic horizon. According to Borken and Brumme (1997), the contribution of organic layer to $\mathrm{N}_{2} \mathrm{O}$ fluxes can be significant, although the response depends on the type of organic horizons. Under L. oblonga and B. ischcemum, the higher SOC input on the forest floor increases the nutrient content and improves soil structure. It is possible that the improvement in soil structure and aeration produced conditions that were less anaerobic and subsequently, anaerobic microorganisms were less likely to be present (Merino et al., 2004). This could explain the differences in $\mathrm{N}_{2} \mathrm{O}$ fluxes from other stands. The relatively high annual $\mathrm{N}_{2} \mathrm{O}$ emissions we recorded for the $Z$. jujube were similar to the findings of Shrestha et al. (2009), where the high $\mathrm{N}_{2} \mathrm{O}$ fluxes from the $Z$. jujube forest may be attributed to the missing of organic layer and higher soil TN concentrations from regular fertilization $\left(150 \mathrm{~kg} \mathrm{~N} \mathrm{ha}^{-1} \mathrm{yr}^{-1}\right)$. Litter removal did not have an important effect on $\mathrm{N}_{2} \mathrm{O}$ emissions, as found by Tang et al. (2006) and Peichl et al. (2010), suggesting that nitrification and denitrification mainly take place in the mineral soil rather than in the surface litter (Tang et al., 2006). $\mathrm{N}_{2} \mathrm{O}$ fluxes showed no significant correlation with ST or SM (Table 5), which is not uncommon to encounter (Groffman et 
al., 2000). However, $\mathrm{N}_{2} \mathrm{O}$ fluxes from $L$. oblonga, P. granatum, and $Z$. jujube were significantly positively correlated with BD (Table 5). Soil pH showed no correlation with soil $\mathrm{N}_{2} \mathrm{O}$ fluxes in our study, indicating that slightly alkaline conditions do not support high $\mathrm{N}_{2} \mathrm{O}$ production (Weslien et al., 2009).

\subsection{Global warming potential}

The combined effect of $\mathrm{CO}_{2}, \mathrm{CH}_{4}$ and $\mathrm{N}_{2} \mathrm{O}$ exchanges contribute to the net ecosystem GWP. The average net GWP of naturally regenerated and managed forest was 12.9 and $21.5 \mathrm{Mg} \mathrm{CO}_{2}$-C equivalent ha ${ }^{-1} \mathrm{yr}^{-1}$, respectively (Table 7). Dalal and Allen (2008) reported a decrease in GWP in natural forest ecosystems, mostly as $\mathrm{CO}_{2}$ sinks in plant biomass, microbial biomass, and soil C. The lower net GWPs of natural vegetation suggest that GWP can be minimized though preservation or restoration of existing ecosystems. In terms of GWP, the relative contribution of $\mathrm{CO}_{2}$ on net GWP was $104.9 \%$, and the contribution of $\mathrm{CH}_{4}$ and $\mathrm{N}_{2} \mathrm{O}$ was -1.6 and $-3.4 \%$, respectively (Table 7). $\mathrm{CO}_{2}$ was the overwhelmingly dominant GHG in all tree species studied, and $\mathrm{CH}_{4}$ and $\mathrm{N}_{2} \mathrm{O}$ sinks had limited impacts on each individual GHG and net GWP of the three GHGs combined.

\subsection{Forest management}

Forest management practices include fertilization, irrigation, and weeding. In the local Taihang Mountian area, the typical forest management practices of $R$. pseudoacacia, P. granatum, and $Z$. jujube are given in Table 2. Forest management of plantation has an obvious effect on GHG emissions by changing soil hydrothermal condition, soil nutrient content, and soil structure (Waterworth and Richards, 2008). Haynes and Gower (1995) showed that the addition of mineral fertilizer ( $\mathrm{N}, \mathrm{P}, \mathrm{K}, \mathrm{Ca}, \mathrm{Mg}, \mathrm{S})$ induced a decrease in soil respiration and fine root production of a coniferous forest soil. Weeding loosens the soil, improves soil aeration, increases the exposure of soil organic matter and speeds up organic matter oxidation, intensifying $\mathrm{CO}_{2}$ emission from the soil to the atmosphere (Jabro et al., 2008). In arid and semi-arid regions, Irrigation increases $\mathrm{CO}_{2}$ emission from the soil surface to the atmosphere by changing soil temperature and soil moisture (Jabro et al., 2008). In this study, no control experiments were set up to evaluate the impact of management practices on soil GHG fluxes, hence it is unknown whether the difference of GHG fluxes between $P$. granatum and $Z$. jujube is caused by tree species or by forest management. It is recommended that the impact of forest management on GHG emissions from $P$. granatum and $Z$. jujube be explored in future study. Management practices were not implemented in $R$. pseudoacacia forest except for the first year of planting (Table 2). Tree species differences lead to the differences in GHG emissions among $R$. pseudoacacia, $P$. granatum, and $Z$. jujube. Different tree species differ in productivity, litter quality and quantity, canopy structure, and nitrogen deposition, eventually lead to large differences in soil GHG emissions (Oostra et al., 2006).

\section{Conclusions}

Soil $\mathrm{CO}_{2}$ emissions from all tree species were significantly affected by ST, SM, and their interaction. $\mathrm{CO}_{2}$ emissions also demonstrated clear seasonal patterns, with fluxes being significantly higher during the warm rainy season than during the cool dry season. However, soil $\mathrm{CH}_{4}$ and $\mathrm{N}_{2} \mathrm{O}$ fluxes were not significantly correlated with ST, soil SM, or their interaction, and no significant seasonal differences were detected. SOC and TN were significantly positively correlated with $\mathrm{CO}_{2}$ and $\mathrm{N}_{2} \mathrm{O}$ fluxes, BD was significantly positively correlated with $\mathrm{CO}_{2}$ fluxes and negatively correlated with $\mathrm{N}_{2} \mathrm{O}$ fluxes, while $\mathrm{pH}$ did not correlate with $\mathrm{CO}_{2}$ and $\mathrm{N}_{2} \mathrm{O}$ emissions. Soil $\mathrm{CH}_{4}$ fluxes showed no dependency on SOC, TN, $\mathrm{BD}$ or soil $\mathrm{pH}$. Soil surface litter removal resulted in significant decreases in $\mathrm{CO}_{2}$ emissions and $\mathrm{CH}_{4}$ uptakes, but had no significant influence on $\mathrm{N}_{2} \mathrm{O}$ fluxes.

For all six tree species, soils acted as sinks for atmospheric $\mathrm{CH}_{4}$. With the exception of $B$. ischcemum, soils acted as sinks for atmospheric $\mathrm{N}_{2} \mathrm{O}$. Tree species significantly affected $\mathrm{CO}_{2}$ and $\mathrm{N}_{2} \mathrm{O}$ fluxes but not $\mathrm{CH}_{4}$ uptakes, with higher rates from managed forests than that from naturally regenerated forests. GHG emission potentials evaluated for different tree species indicated the net GWPs were lower in naturally regenerated vegetation, suggesting that natural vegetation is more desirable in reducing global warming. Enhanced GHG fluxes between soils and the atmosphere in managed forests suggest that the soil-atmospheric GHG fluxes in forests on Taihang Mountain may increase further if the large areas of secondary forests are destroyed. Thus, preservation or restoration of existing ecosystems should be the primary goal of carbon sequestration.

Acknowledgements. This research was supported by the National Natural Science Foundation of China (31000251), "Strategic Priority Research Program" of the Chinese Academy of Sciences (XDA05060600), and Project of Efficient Utilization of Agricultural Resources (KSCX2-EW-J-5). We would like to thank Scott David Roberts and Yanjiang Cai who helped to improve greatly the quality of this manuscript.

Edited by: Z. Xie

\section{References}

Angel, R., Claus, P., and Conrad, R.: Methanogenic archaea are globally ubiquitous in aerated soils and become active under wet anoxic conditions, ISME J., 6, 847-862, 2012.

Beauchamp, E. G.: Nitrous oxide emission from agricultural soils, Can. J. Soil Sci., 77, 113-123, 1997. 
Berger, T. W., Inselsbacher, E., and Zechmeister-Boltenstern, S.: Carbon dioxide emissions of soils under pure and mixed stands of beech and spruce, affected by decomposing foliage litter mixtures, Soil Biol. Biochem., 42, 986-997, 2010.

Bodelier, P. L. E. and Laanbroek, H. J.: Nitrogen as a regulatory factor of methane oxidation in soils and sediments, FEMS Microbiol. Ecol., 47, 265-277, 2004.

Borken, W. and Beese F.: Control of nitrous oxide emissions in European beech, Norway spruce and Scots pine forests, Biogeochemistry, 76, 141-159, 2005.

Borken, W. and Brumme, R.: Liming practice in temperate forest ecosystems and the effects on $\mathrm{CO}_{2}, \mathrm{~N}_{2} \mathrm{O}$ and $\mathrm{CH}_{4}$ fluxes, Soil Use Manage., 13, 157-251, 1997.

Borken, W., Xu, Y. J., and Beese, F.: Conversion of hardwood forests to spruce and pine plantations strongly reduced soil methane sink in Germany, Glob. Change Biol., 9, 956-966, 2003.

Campbell, J. L. and Law, B. E.: Forest soil respiration across three climatically distinct chronosequences in Oregon, Biogeochemistry, 73, 109-125, 2005.

Canadell, J. G. and Raupach, M. R.: Managing forests for climate change mitigation, Science, 320, 1456-1457, 2008.

Chapman, S. J. and Thurlow, M.: The influence of climate on $\mathrm{CO}_{2}$ and $\mathrm{CH}_{4}$ emissions from organic soils, Agr. Forest Meteorol., 79, 205-217, 1996.

Chapuis-Lardy, L., Wrage, N., Metay, A., Chotte, J.-L., and Bernoux, M.: Soils, a sink for $\mathrm{N}_{2} \mathrm{O}$ ? A review, Glob. Change Biol., 13, 1-17, 2007.

Chen, G. C., Tam, N. F. Y., and Ye, Y.: Summer fluxes of atmospheric greenhouse gases $\mathrm{N}_{2} \mathrm{O}, \mathrm{CH}_{4}$ and $\mathrm{CO}_{2}$ from mangrove soil in South China, Sci. Total Environ., 408, 2761-2767, 2010.

Christiansen, J. R. and Gundersen, P.: Stand age and tree species affect $\mathrm{N}_{2} \mathrm{O}$ and $\mathrm{CH}_{4}$ exchange from afforested soils, Biogeosciences, 8, 2535-2546, doi:10.5194/bg-8-2535-2011, 2011.

Christiansen, J. R., Vesterdal, L., and Gundersen, P.: Nitrous oxide and methane exchange in two small temperate forest catchmentseffects of hydrological gradients and implications for global warming potentials of forest soils, Biogeochemistry, 107, 437454, 2012.

Dalal, R. C. and Allen, D. E.: Turner review no.18 greenhouse gas fluxes from natural ecosystems, Aust. J. Bot., 56, 369-407, 2008.

Davidson, E. A., Janssens, I. A., and Luo, Y. Q.: On the variability of respiration in terrestrial ecosystems: moving beyond $Q_{10}$, Glob. Change Biol., 12, 154-164, 2006.

Degelmann, D. M., Borken, W., and Kolb, S.: Methane oxidation kinetics differ in European beech and Norway spruce soils, Eur. J. Soil Sci., 60, 499-506, 2009.

Dewar, R. C. and Cannell, M. G. R.: Carbon sequestration in the trees, products and soils of forest plantations: an analysis using UK examples, Tree Physiol., 11, 49-71, 1992.

Dobbie, K. E., McTaggart, I. P., and Smith, K. A.: Nitrous oxide emissions from intensive agricultural systems: Variations between crops and seasons, key driving variables, and mean emission factors, J. Geophys. Res., 104, 26891-26899, 1999.

Eickenscheidt, N. and Brumme, R.: $\mathrm{NO}_{\mathrm{x}}$ and $\mathrm{N}_{2} \mathrm{O}$ fluxes in a nitrogen-enriched European spruce forest soil under experimental long-term reduction of nitrogen depositions, Atmos. Environ., 60, 51-58, 2012.
Fang, C., Moncrieff, J. B., Gholz, H. L., and Clark, K. L.: Soil $\mathrm{CO}_{2}$ efflux and its spatial variation in a Florida slash pine plantation, Plant Soil, 205, 135-146, 1998.

Goldberg, S. D. and Gebauer, G.: Drought turns a Central European Norway spruce forest soil from an $\mathrm{N}_{2} \mathrm{O}$ source to a transient $\mathrm{N}_{2} \mathrm{O}$ sink, Glob. Change Biol., 15, 850-860, 2009.

Grigal, D. F. and Ohmann, L. F.: Carbon storage in upland forests of the Lake States, Soil Sci. Soc. Am. J., 56, 935-943, 1992.

Groffman, P. M., Brumme, R., Butterbach-Bahl, K., Dobbie, K. E., Mosier, A. R., Ojima, D., Papen, H., Parton, W. J., Smith, K. A., and Wagner-Riddle, C.: Evaluating annual nitrous oxide fluxes at the ecosystem scale, Global Biogeochem. Cy., 14, 1061-1070, 2000.

Gundersen, P., Christiansen, J. R., Alberti, G., Brüggemann, N., Castaldi, S., Gasche, R., Kitzler, B., Klemedtsson, L., Lobo-doVale, R., Moldan, F., Rütting, T., Schleppi, P., Weslien, P., and Zechmeister-Boltenstern, S.: The response of methane and nitrous oxide fluxes to forest change in Europe, Biogeosciences, 9, 3999-4012, doi:10.5194/bg-9-3999-2012, 2012.

Haynes, B. E. and Gower, S. T.: Belowground carbon allocation in unfertilized and fertilized red pine plantations in northern Wisconsin, Tree Physiol., 15, 317-325, 1995.

Inclán, R., Uribe, C., Sánchez, L., Sánchez, D. M., Clavero, Á., Fernández, A. M., Morante, R., Blanco, A., and Jandl, R.: $\mathrm{N}_{2} \mathrm{O}$ and $\mathrm{CH}_{4}$ fluxes in undisturbed and burned holm oak, scots pine and pyrenean oak forests in central Spain, Biogeochemistry, 107, 19$41,2012$.

Inubushi, K., Furukawa, Y., Hadi, A., Purnomo, E., and Tsuruta, $\mathrm{H}$.: Seasonal changes of $\mathrm{CO}_{2}, \mathrm{CH}_{4}$ and $\mathrm{N}_{2} \mathrm{O}$ fluxes in relation to land-use change in tropical peatlands located in coastal area of South Kalimantan, Chemosphere, 52, 603-608, 2003.

Iqbal, J., Hu, R. G., Lin, S., Ahamadou, B., and Feng, M. L.: Carbon dioxide emissions from Ultisol under different land uses in midsubtropical China, Geoderma, 152, 63-73, 2009.

Iqbal, J., Hu, R. G., Feng, M. L., Lin, S., Malghani, S., and Ali, I. M.: Microbial biomass, and dissolved organic carbon and nitrogen strongly affect soil respiration in different land uses: A case study at Three Gorges Reservoir Area, South China, Agr. Ecosyst. Environ., 137, 294-307, 2010.

Jabro, J. D., Sainju, U., Stevens, W. B., and Evans, R. G.: Carbon dioxide flux as affected by tillage and irrigation in soil converted from perennial forages to annual crops, J. Environ. Manage., 88, 1478-1484, 2008.

Kellman, L. and Kavanaugh, K.: Nitrous oxide dynamics in managed northern forest soil profiles: is production offset by consumption?, Biogeochemistry, 90, 115-128, 2008.

Ladegaard-Pedersen, P., Elberling, B., and Vesterdal, L.: Soil carbon stocks, mineralization rates, and $\mathrm{CO}_{2}$ effluxes under 10 tree species on contrasting soil types, Can. J. Forest Res., 35, $1277-$ $1284,2005$.

Lang, M., Cai, Z. C., Mary, B., Hao, X. Y., and Chang, S. X.: Landuse type and temperature affect gross nitrogen transformation rates in Chinese and Canadian soils, Plant Soil, 334, 377-389, 2010.

Law, B. E., Thornton, P. E., Irvine, J., Anthoni, P. M., and Van Tuyl, S.: Carbon storage and fluxes in ponderosa pine forests at different developmental stages, Glob. Change Biol., 7, 755-777, 2001. 
Le Mer, J. and Roger, P.: Production, oxidation, emission and consumption of methane by soils: a review, Eur. J. Soil Biol., 37, 25-50, 2001.

Li, Y. L., Peng, S. L., Zhao, P., Ren, H., and Li, Z. A.: A study on the soil carbon storage of some land use types in Heshan, Guangdong, China, J. Mt. Sci., 20, 548-552, 2002 (in Chinese).

Liu, H., Zhao, P., Lu, P., Wang, Y. S., Lin, Y. B., and Rao, X. Q.: Greenhouse gas fluxes from soils of different land-use types in a hilly area of South China, Agr. Ecosyst. Environ., 124, 125-135, 2008.

Liu, X., Zhang, W., Liu, Z., Qu, F., and Tang, X.: Changes in species diversity and above-ground biomass of shrubland over long-term natural restoration process in the Taihang Mountain in North China, Plant Soil Environ., 57, 505-512, 2011.

Liu, X. J., Mosier, A. R., Halvorson, A. D., and Zhang, F. S.: The impact of nitrogen placement and tillage on $\mathrm{NO}, \mathrm{N}_{2} \mathrm{O}, \mathrm{CH}_{4}$ and $\mathrm{CO}_{2}$ fluxes from a clay loam soil, Plant Soil, 280, 177-188, 2006.

Liu, X. P., Zhang, W. J., Liu, Z. J., Qu, F., and Song, W. F.: Impacts of land cover changes on soil chemical properties in Taihang Mountain, China, J. Food Agr. Environ., 8, 985-990, 2010.

Luo, G.J., Brüggemann, N., Wolf, B., Gasche, R., Grote, R., and Butterbach-Bahl, K.: Decadal variability of soil $\mathrm{CO}_{2}, \mathrm{NO}, \mathrm{N}_{2} \mathrm{O}$, and $\mathrm{CH}_{4}$ fluxes at the Höglwald Forest, Germany, Biogeosciences, 9, 1741-1763, doi:10.5194/bg-9-1741-2012, 2012.

Ma, X. Z., Zhang, Q. L., Li, C. S., Chen, G. W., and Wang, F.: Temporal variation of soil greenhouse gases fluxes in a coldtemperate Larix gmelinii forest in Inner Mongolia, China, Chin. J. Appl. Ecol., 23, 2149-2156, 2012 (in Chinese).

Mapanda, F., Mupini, J., Wuta, M., Nyamangara, J., and Rees, R. M.: A cross-ecosystem assessment of the effects of land cover and land use on soil emission of selected greenhouse gases and related soil properties in Zimbabwe, Eur. J. Soil Sci., 61, 721733,2010

Mayer, H. P. and Conrad, R.: Factors influencing the population of methanogenic bacteria and the initiation of methane production upon flooding of paddy soil, FEMS Microbiol. Lett., 73, 103111. 1990

Merino, A., Pérez-Batallón, P., and Macías, F.: Responses of soil organic matter and greenhouse gas fluxes to soil management and land use changes in a humid temperate region of southern Europe, Soil Biol. Biochem., 36, 917-925, 2004.

Nishina, K., Takenaka, C., and Ishizuka, S.: Relationship between $\mathrm{N}_{2} \mathrm{O}$ and $\mathrm{NO}$ emission potentials and soil properties in Japanese forest soils, Soil Sci. Plant Nutr., 55, 203-214, 2009.

Oostra, S., Majdi, H., and Olsson, M.: Impact of tree species on soil carbon stocks and soil acidity in southern Sweden, Scand. J. Forest Res., 21, 364-371, 2006.

Peichl, M., Arain, M. A., Ullah, S., and Moore, T. R.: Carbon dioxide, methane, and nitrous oxide exchanges in an age-sequence of temperate pine forests, Glob. Change Biol., 16, 2198-2212, 2010

Post, W. M. and Kwon, K. C.: Soil carbon sequestration and landuse change: processes and potential, Glob. Change Biol., 6, 317327,2000

Raich, J. W. and Tufekcioglu, A.: Vegetation and soil respiration: Correlations and controls, Biogeochemistry, 48, 71-90, 2000.

Rosenkranz, P., Brüggemann, N., Papen, H., Xu, Z., Seufert, G., and Butterbach-Bahl, $\mathrm{K} .: \mathrm{N}_{2} \mathrm{O}$, $\mathrm{NO}$ and $\mathrm{CH}_{4}$ exchange, and mi- crobial $\mathrm{N}$ turnover over a Mediterranean pine forest soil, Biogeosciences, 3, 121-133, doi:10.5194/bg-3-121-2006, 2006.

Saiz, G., Green, C., Butterbach-Bahl, K., Kiese, R., Avitable, V., and Farrell, E. P.: Seasonal and spatial variability of soil respiration in four Sitka spruce stands, Plant Soil, 287, 161-176, 2006.

Sharma, C. M., Gairola, S., Baduni, N. P., Ghildiyal, S. K., and Suyal, S.: Variation in carbon stocks on different slope aspects in seven major forest types of temperate region of Garhwal Himalaya, India, J. Bioscience, 36, 701-708, 2011.

Shrestha, R. K., Lal, R., and Penrose, C.: Greenhouse gas emissions and global warming potential of reclaimed forest and grassland soils, J. Environ. Qual., 38, 426-436, 2009.

Stewart, K. J., Brummell, M. E., Farrell, R. E., and Siciliano, S. D.: $\mathrm{N}_{2} \mathrm{O}$ flux from plant-soil systems in polar deserts switch between sources and sinks under different light conditions, Soil Biol. Biochem., 48, 69-77, 2012.

Tang, X. L., Liu, S. G., Zhou, G. Y., Zhang, D. Q., and Zhou, C. Y.: Soil-atmospheric exchange of $\mathrm{CO}_{2}, \mathrm{CH}_{4}$, and $\mathrm{N}_{2} \mathrm{O}$ in three subtropical forest ecosystems in southern China, Glob. Change Biol., 12, 546-560, 2006.

USEPA: Inventory of U.S. greenhouse gas emissions and sinks: 1990-2010, Washington, DC, 2012.

Verchot, L. V., Davidson, E. A., Cattânio, J. H., and Ackerman, I. L.: Land-use change and biogeochemical controls of methane fluxes in sols of eastern Amazonia, Ecosystems, 3, 41-56, 2000.

Vesterdal, L., Schmidt, I. K., Callesen, I., Nilsson, L. O., and Gundersen, P.: Carbon and nitrogen in forest floor and mineral soil under six common European tree species, Forest Ecol. Manag., 255, 35-48, 2008.

Vesterdal, L., Elberling, B., Christiansen, J. R., Callesen, I., and Schmidt, I. K.: Soil respiration and rates of soil carbon turnover differ among six common European tree species, Forest Ecol. Manag., 264, 185-196, 2012.

Vincent, G., Shahriari, A. R., Lucot, E., Badot, P.-M., and Epron, D.: Spatial and seasonal variations in soil respiration in a temperate deciduous forest with fluctuating water table, Soil Biol. Biochem., 38, 2527-2535, 2006.

Vose, J. M. and Bolstad P. V.: Biotic and abiotic factors regulating forest floor $\mathrm{CO}_{2}$ flux across a range of forest age classes in the southern Appalachians, Pedobiologia, 50, 577-587, 2006.

Wang, Y. S. and Wang, Y. H.: Quick measurement of $\mathrm{CH}_{4}, \mathrm{CO}_{2}$ and $\mathrm{N}_{2} \mathrm{O}$ emissions from a short-plant ecosystem, Adv. Atmos. Sci., 20, 842-844, 2003.

Wang, Y. S., Xue, M., Zheng, X. H., Ji, B. M., Du, R., and Wang, Y. F.: Effects of environmental factors on $\mathrm{N}_{2} \mathrm{O}$ emission from and $\mathrm{CH}_{4}$ uptake by the typical grasslands in the Inner Mongolia, Chemosphere, 58, 205-215, 2005.

Waterworth, R. M. and Richards, G. P.: Implementing Australian forest management practices into a full carbon accounting model, Forest Ecol. Manag., 255, 2434-2443,2008.

Weslien, P., Kasimir Klemedtsson, ̊., BöRjesson, G., and Klemedtsson, L.: Strong pH influence on $\mathrm{N}_{2} \mathrm{O}$ and $\mathrm{CH}_{4}$ fluxes from forested organic soils, Eur. J. Soil Sci., 60, 311-320, 2009.

$\mathrm{Xu}, \mathrm{M}$. and Qi, Y.: Soil-surface $\mathrm{CO}_{2}$ efflux and its spatial and temporal variations in a young ponderosa pine plantation in northern California, Glob. Change Biol., 7, 667-677, 2001.

Yan, J. H., Wang, Y. P., Zhou, G. Y., and Zhang, D. Q.: Estimates of soil respiration and net primary production of three forests at 
different succession stages in South China, Glob. Change Biol., 12, 810-821, 2006.

Yang, Y. S., Guo, J. F., Chen, G. S., Xie, J. S., Gao, R., Li, Z., and Jin, Z.: Carbon and nitrogen pools in Chinese fir and evergreen broadleaved forests and changes associated with felling and burning in mid-subtropical China, Forest Ecol. Manag., 216, 216-226, 2005.

Yao, Z. S., Wolf, B., Chen, W. W., Butterbach-Bahl, K., Brüggemann, N., Wiesmeier, M., Dannenmann, M., Blank, B., and Zheng, X. H.: Spatial variability of $\mathrm{N}_{2} \mathrm{O}, \mathrm{CH}_{4}$ and $\mathrm{CO}_{2}$ fluxes within the Xilin River catchment of Inner Mongolia, China: a soil core study, Plant Soil, 331, 341-359, 2010.

Young, R., Wilson, B. R., Mcleod, M., and Alston, C.: Carbon storage in the soils and vegetation of contrasting land uses in northern New South Wales, Australia, Aust. J. Soil Res., 43, 21-31, 2005 .
Zhang, J. T., Xi, Y., and Li, J.: The relationships between environment and plant communities in the middle part of Taihang Mountain Range, North China, Community Ecol., 7, 155-163, 2006.

Zhang, K., Dang, H., Tan, S., Cheng, X., and Zhang, Q.: Change in soil organic carbon following the "grain-for-green" programme in china, Land Degrad. Dev., 21, 13-23, 2010.

Zhang, P. C., Shao, G. F., Zhao, G., Le Master, D. C., Parker, G. R., Dunning, J. B., and Li, Q. L.: Ecology: China's forest policy for the 21st century, Science, 288, 2135-2136, 2000.

Zheng, H., Ouyang, Z. Y., Xu, W. H., Wang, X. K., Miao, H., Li, X. Q., and Tian, Y. X.: Variation of carbon storage by different reforestation types in the hilly red soil region of southern China, Forest Ecol. Manag., 255, 1113-1121, 2008.

Zhou, L. X., Yi, W. M., Yi, Z. G., Li, Z. A., and Ding, M. M.: Soil microbial characteristics in rehabilitation process of degraded ecosystems in Heshan, J. Trop. Subtrop. Bot., 12, 202-206, 2004 (in Chinese). 